\title{
Melanoma Brain Metastasis: Mechanisms, Models, and Medicine
}

\author{
David A. Kircher ${ }^{1, \dagger}$, Mark R. Silvis ${ }^{2,+}$, Joseph H. Cho ${ }^{1}$ and Sheri L. Holmen ${ }^{1,2,3, *}$ \\ 1 Department of Oncological Sciences, University of Utah Health Sciences Center, Salt Lake City, UT 84112, \\ USA; david.kircher@hci.utah.edu (D.A.K.); joe.cho@hsc.utah.edu (J.H.C.) \\ 2 Department of Surgery, University of Utah Health Sciences Center, Salt Lake City, UT 84112, USA; \\ mark.silvis@hci.utah.edu \\ 3 Huntsman Cancer Institute, University of Utah Health Sciences Center, Salt Lake City, UT 84112, USA \\ * Correspondence: sheri.holmen@hci.utah.edu; Tel.: +1-801-213-4237 \\ + These authors contributed equally to this work.
}

Academic Editor: Dario Marchetti

Received: 2 August 2016; Accepted: 26 August 2016; Published: 2 September 2016

\begin{abstract}
The development of brain metastases in patients with advanced stage melanoma is common, but the molecular mechanisms responsible for their development are poorly understood. Melanoma brain metastases cause significant morbidity and mortality and confer a poor prognosis; traditional therapies including whole brain radiation, stereotactic radiotherapy, or chemotherapy yield only modest increases in overall survival (OS) for these patients. While recently approved therapies have significantly improved OS in melanoma patients, only a small number of studies have investigated their efficacy in patients with brain metastases. Preliminary data suggest that some responses have been observed in intracranial lesions, which has sparked new clinical trials designed to evaluate the efficacy in melanoma patients with brain metastases. Simultaneously, recent advances in our understanding of the mechanisms of melanoma cell dissemination to the brain have revealed novel and potentially therapeutic targets. In this review, we provide an overview of newly discovered mechanisms of melanoma spread to the brain, discuss preclinical models that are being used to further our understanding of this deadly disease and provide an update of the current clinical trials for melanoma patients with brain metastases.
\end{abstract}

Keywords: melanoma; brain metastases; mechanisms; models; clinical trials

\section{Tumor Cell Metastasis}

Metastasis is a complex, multi-step process resulting in the spread of tumor cells from a primary lesion to a disparate organ or organs within the body, that results in increased patient morbidity and mortality [1]. Metastatic cells acquire unique characteristics that enable them to proliferate and migrate, invade the local normal tissue, intravasate through the basement membrane into blood or lymphatic vessels, survive during circulation through the blood stream or lymphatic system, arrest at distant sites, extravasate into the surrounding tissue, and proliferate by inducing angiogenesis [1]. In addition to cancer cell-autonomous phenotypes that enable this process to occur, the microenvironment of the metastatic site also provides pro-tumorigenic signals, innately, or in response to the metastasis itself, which promote survival, migration, and growth of disseminated tumor cells at secondary sites $[2,3]$. The brain microenvironment is a unique physiological niche due to its highly selective blood-brain barrier (BBB), high-energy consumption and nutritional demands, and immune privilege [4]. During the final stages of melanoma cell metastasis in the brain, circulating tumor cells adhere to the vasculature and bypass the $\mathrm{BBB}$, the specialized multicellular layer that protects the brain, thereby establishing secondary neoplasms within the brain. Several lines of evidence 
suggest that metastatic melanoma cells are genetically evolved from their primary site predecessors and thus have acquired phenotypes that select for cerebrotropism [5-7]. In addition, the brain milieu provides necessary cues for survival, migration, proliferation, and angiogenesis, thus facilitating melanoma brain metastasis. The following review provides an overview of our current mechanistic understanding of melanoma brain metastasis formation, a more detailed overview of the role of the AKT/PI3K pathway in melanoma progression, an examination of models used to study these processes, and an update of current clinical trials for melanoma patients with brain metastases.

\section{Mechanisms of Melanoma Brain Metastasis}

Metastatic brain tumors are the most common intracranial neoplasm in adults [8]. To better understand the formation of brain metastases, the Winkler lab used a mouse with a chronic cranial window to track the fate of fluorescently labeled melanoma cells during their colonization of the mouse brain. They characterized the steps of the late metastatic cascade as: cell arrest at vascular branch points, early extravasation, persistent close contact to microvessels, perivascular growth by vessel co-option, and angiogenesis [9]. These steps provide a general framework in which to discuss the mechanisms underlying intracranial melanoma metastasis formation (Figure 1).

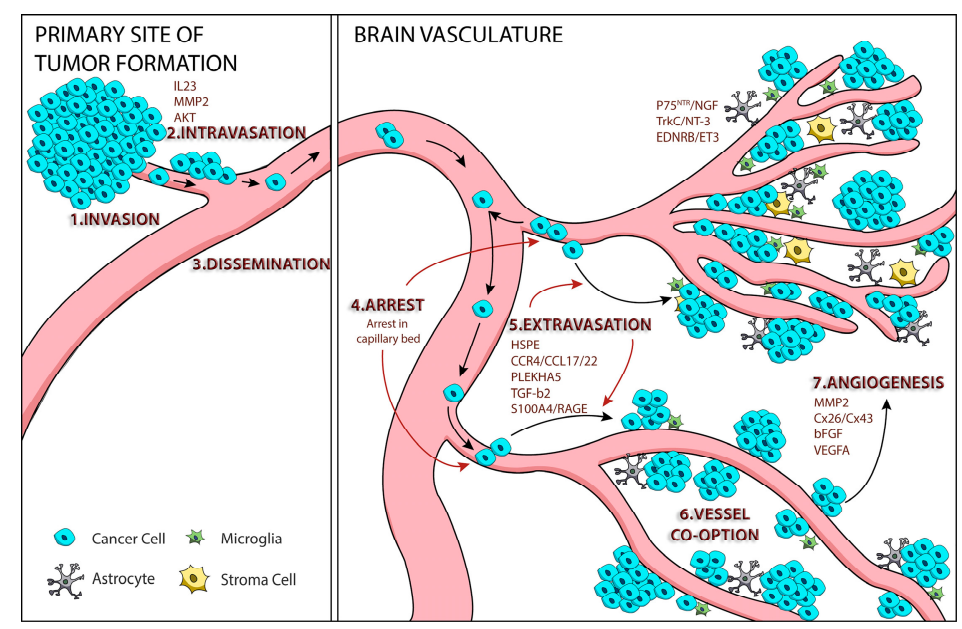

Figure 1. Steps and factors involved in melanoma metastasis to the brain.

\subsection{Melanoma Cell Arrest within the Brain Microvasculature}

To address how passively diffusing, disseminated metastatic melanoma cells arrive at the brain microvasculature and establish a secondary neoplasm, Kienast et al. examined the specific intravascular location of metastases formation. They noted that movement of the injected cells through the blood vessels of the brain was initially halted as the diameter of the microvessels decreased to a size comparable with that of the cells, and especially at vascular branch points [9]. This suggests that disseminated metastatic melanoma cells can become physically lodged within brain capillaries. The pattern of blood flow throughout the body and mechanical limitations presented by the vasculature both influence metastatic establishment of cancer cells at distinct organs [10]. In addition to the physical impediment of cell mobility caused by microvessel size or bifurcation, it is well documented that metastatic melanoma cells also display increased adhesion to the brain endothelium, as compared to non-metastatic melanoma cells, or even metastatic breast cancer cells [11-13]. Several adhesion molecules that were originally described in leukocytes and platelets, including selectins, integrins, cell adhesion molecules, tetraspanins, and others, have been shown to mediate metastatic cell binding to the brain endothelium (reviewed in [14]); however, to what extent each of these adhesion molecules contributes to the colonization of the brain by melanoma cells specifically is either not known or poorly understood. 
Kienast et al. also noted that arrested cells were able to evacuate from their initial resting place and subsequently relocate to another site within the brain vasculature [9]. This observation corroborates what other studies have shown-that disseminated melanoma cells can be directed to and/or selectively retained within the brain by external cues originating in the parenchymal milieu, such as chemokines or brain-derived ligands. Chemokine stimulation of their respective receptors is known to induce cellular responses of altered adhesion, migration, proliferation, and apoptosis [15]. Brain-derived signals promote melanoma cell adhesion to the intracranial vasculature and concomitantly foster melanoma metastases formation, which is the "seed and soil" hypothesis of cancer cell metastasis originally proposed by Paget in 1889 [16].

The role of chemokines and their cognate receptors in directing organ-specific melanoma metastasis has been documented for lymph node and pulmonary metastases. The $\mathrm{C}-\mathrm{C}$ chemokine receptor type 7 (CCR7) promotes melanoma cell metastasis to the C-C motif ligand 21 (CCL21)-rich lymph nodes while the C-X-C chemokine receptor type 4 (CXCR4)/C-X-C motif chemokine ligand 12 (CXCL12) axis facilitates pulmonary metastasis $[17,18]$. Izraely et al. provided evidence for chemokine-mediated homing of disseminated melanoma cells to the brain using nude-BALB/c mice and implants of YDFR human melanoma cells to generate primary and brain metastatic tumors, from which cell lines were derived [19]. Although these cell lines were of the same genetic background, primary tumor-derived cells expressed low levels of the chemokine receptor CCR4, whereas brain-metastasizing melanoma cells expressed significantly higher levels of CCR4. CCR4 has already been shown to direct organ-specific metastasis of breast, colorectal, and gastric cancers [20-22]. Furthermore, "brain-derived soluble factors" upregulate CCR4 expression in melanoma cells and enhance the migration of brain-metastasizing melanoma cells specifically; however, whether these soluble factors are the brain-expressed CCR4 ligands, CCL17 or CCL22, and whether this signaling axis promotes melanoma brain metastasis remains to be determined [23]. Recently, an examination of the chemokine and cytokines (immunokines) within the cerebrospinal fluid of a small number of patients with melanoma brain metastases reported global reconfigurations of immunokine profiles. Lok et al. observed a significant correlation between poor clinical outcomes and alterations in several CCR4-binding immunokines, including CCL22, CCL4, and CCL17 [24]. These correlations suggest that changes in the intracranial "immunokine" profile may facilitate the establishment of brain metastases by melanoma cells through altered cytokine and receptor signaling that positively influences the retention or homing of disseminated melanoma cells to the brain. Whether these changes are a result of autocrine signaling by melanoma metastases or changes in the brain parenchyma in response to the metastases has not been determined. Further, it is not known whether such alterations enable metastasis progression or promote additional brain metastases. Additional studies like these need to be conducted with larger sample sizes to determine the significance of these differences and the correlation with disease progression and overall survival. Such data could then warrant additional studies to examine the effects of artificially modulating specific immunokines within the CSF to determine how these alterations influence melanoma brain metastasis.

Endothelin receptor B (EDNRB), a G protein-coupled receptor that is upregulated in melanoma metastases [25], is another molecule that could enable the preferential colonization of the brain by melanoma. Cruz-Munoz et al. used a xenograft mouse model of melanoma brain metastasis to demonstrate that EDNRB overexpression enhanced the metastatic potential of the implanted tumor cells, which resulted in more brain metastases compared with control tumor cells [26]. Blocking EDNRB specifically negated the enhanced metastatic phenotype and resulted in an increased overall survival in the mice. Furthermore, one of the EDNRB ligands, ET3, is highly expressed in the brain [27] and studies evaluating the clinical application of EDNRB antagonists are currently underway [18,28].

In the mid-1970s, researchers noted that melanoma cells had a very high density of receptors for, and strong affinity towards, neurotrophins such as nerve growth factor (NGF). This suggested that a ligand-receptor interaction could be the basis for melanoma's predilection for the brain [29]. Subsequent studies have determined that $\mathrm{p} 75^{\mathrm{NTR}}$, a receptor for NGF, is highly upregulated in 
melanoma cells and associated with brain metastasis [30,31]. Other receptors such as TrkC, the putative receptor for neurotrophin-3 (NT-3), are also highly expressed on melanoma cells and suggest that neurotrophins may help recruit metastatic melanoma cells to the brain [32]. Interestingly, astrocytes found at the stromal-tumor interface of melanoma brain metastases display increased expression of neurotrophins like NGF and NT-3, further supporting the hypothesis that these ligands originate from the brain and support melanoma cell metastasis [33,34].

High endogenous expression of transforming growth factor- $\beta 2$ (TGF- $\beta 2$ ), which is an isoform of TGF- $\beta$ [35], was able to direct melanoma cells to form brain metastases within the parenchyma of mice, while low expression of TGF- $\beta 2$ induced brain metastasis within the ventricles and leptomeninges [36]. Reducing expression levels of TGF- $\beta 2$ by knockdown with shRNAs significantly inhibited brain parenchyma metastasis, suggesting that melanoma cell expression of TGF- $\beta 2$ controls, or is required for, the site-specific colonization of metastatic melanoma. Recently, the levels of a microRNA (miRNA) that controls the expression of TGF- $\beta 2$ was shown to be dramatically decreased, with a concomitant increase in expression of TGF- $\beta 2$, in human melanoma cell lines [37]. Forced expression of miR-328 inhibited proliferation by inducing cell cycle arrest in human melanoma cells [37]. Future studies should determine how miR-328 levels are controlled and whether it functions through TGF- $\beta 2$ to regulate site-specific melanoma brain metastasis formation. In addition, it will be interesting to understand how TGF- $\beta 2$ determines the fate of melanoma cell localization intracranially. These studies suggest that both melanoma cell autonomous and non-cell-autonomous mechanisms are responsible for the chemokine- and receptor-mediated recruitment, homing, and retention of melanoma cells to the intracranial vasculature. Once localized within the brain, melanoma cells receive tissue-derived cues that potentiate extravasation, the transmigration of metastasizing cells out of the vasculature and across the BBB.

\subsection{Extravasation}

The BBB presents a formidable border that tumor cells must cross in order to establish residence within the brain. The BBB functions as a highly selective and tight interface between the blood within the microvasculature and the parenchyma tissue of the brain. It is composed of continuous, non-fenestrated endothelial cells that are reinforced by an underlying basement membrane and connected by tight junctions [38]. Inter-endothelial tight junctions, composed of transmembrane complexes that link adjacent cells, are extremely tight and thus prevent the passive diffusion of ions and other polar solutes between endothelial cells [39]. Cerebral endothelial cells are supported on their extravascular side, next to the collagen-rich extracellular matrix, by a tightly-associated layer of pericytes along with the foot processes of astrocytes that form a perivascular sheath [38]. One of the main functions of the BBB is to strictly regulate the flow of ions, nutrients, and cells into the brain parenchyma. How melanoma cells are able to cross the BBB is still not completely understood, as it is difficult to study these processes in vivo or in vitro. Kienast et al. noted that successful transendothelial migration of metastasizing cells was highly inefficient and occurred slowly, taking up to 14 days [9]. Several mechanisms for how the cerebral endothelium and arrested melanoma cells interact to enable extravasation, which is thought to occur via a paracellular route, have been described.

Heparanase (HPSE), an enzyme that degrades heparan sulfate chains of proteoglycans enriched in endothelial cell layers, is upregulated in many cancers and correlates with metastatic potential [40]. HPSE may act in a brain-specific manner allowing penetration of the BBB by metastatic melanoma cells [41-43]. The presence of HPSE increases invasion of melanoma cells into brain tissues in brain slice models [43]. Furthermore, co-incubation of brain metastatic melanoma cells with astrocytes results in elevated HPSE activity and an increased invasive phenotype in vitro [42]. The role of HPSE in brain-specific metastasis is further supported by the fact that brain-derived neurotrophins, such as NGF, enhance HPSE activity [44]. More recently, miRNA suppression of HPSE has been shown to inhibit melanoma migration, invasion, and adhesion, but examination of melanoma brain metastasis formation with knockdown of HPSE was not reported [45]. miRNA-mediated knockdown of HPSE 
does suppress breast cancer brain metastasis [46]. Whether targeting HPSE is a therapeutic option for inhibiting melanoma brain metastasis remains to be determined [41].

In vitro studies utilizing confluent brain endothelial cells as a model of the BBB examined transmigration of fluorescently labeled human A2058 and murine B16/F10 melanoma cells lines [47]. Transmigration occurred via the paracellular transmigration pathway, in a process that caused the disruption of the tight junction proteins occludin and claudin-5. Transmigration was partially dependent upon the gelatinolytic serine protease, seprase, as either Pefabloc, a serine protease inhibitor, or siRNA-mediated knockdown of seprase, decreased transmigration through interendothelial junctions [47]. An additional report utilizing an in vitro brain endothelial BBB model demonstrated that melanoma cells transmigrate more rapidly, and have an increased ability to impair tight junctions, when compared withbreast cancer cells [13]. Molnár et al. also showed that adhesion of melanoma cells to the brain endothelial cells requires Rac or PI3K activity, as inhibition of either impaired melanoma cell adhesion and the early phase of transmigration [13]. These studies utilized in vitro models of the BBB to dissect the mechanisms of melanoma cell extravasation, which have proven to be informative. It will be interesting to determine whether these processes are required for the in vivo establishment of melanoma brain metastases.

Several reports have implicated a role for Connexin-26 (Cx26) or Connexin-43 (Cx43), which are the only gap junction proteins expressed in melanocytes [48,49], as having a role in melanoma brain metastasis. Stoletov et al. demonstrated that melanoma cells utilize the gap junction protein Cx26 to associate with the cerebral endothelial cells in chickens during the initiation of brain metastasis [50]. Silencing of Cx26 in melanoma cells inhibited extravasation and in vivo brain colonization [50]. However, these studies were performed with only one mouse cell line (B16) that expresses Cx26 but not $\mathrm{Cx} 43$. Other reports show that patient samples of malignant melanomas have high expression of Cx43 while Cx26 expression is nearly absent [51]. More recently, Cx43 overexpression was found to inhibit melanoma proliferation and metastasis by inducing TGF- $\alpha$-mediated apoptosis but brain metastasis was not reported $[52,53]$. Thus, additional studies on the role of gap junctions in melanoma extravasation into the brain parenchyma are needed.

Recently, Herwig et al. demonstrated a role for high levels of extracellular S100A4, a member of the $\mathrm{S} 100$ calcium-binding protein family, in decreasing inter-endothelial tight junction integrity by using A375 human melanoma cells and an in vitro BBB model $[54,55]$. Paracrine-mediated signaling of S100A4 secreted from melanoma cells with its cognate receptor, receptor for advanced glycation end-products (RAGE), on endothelial cells enabled transmigration. This occurred by reducing expression of the interendothelial tight junction molecules, occludin and VE-cadherin, and inducing a loss of endothelial tightness, as determined by decreases in transendothelial electrical resistance (TEER). They also revealed that brain metastasis formation by A375 cells injected intracardially into athymic mice was increased with overexpression of S100A4/RAGE [54,55]. S100A4/RAGE signaling has been linked to the pro-migratory, invasive, and metastatic characteristics of several tumor types, including thyroid, prostate, and colorectal [56-58]. S100A4/RAGE signals through diaphanous-1 (thyroid cancer), nuclear Factor k B (NFkB) (prostate cancer), and/or mitogen-activated protein kinase (MAPK)/extracellular regulated kinase (ERK) (colorectal) pathways and it will be informative to investigate which intracellular pathways are modulated by S100A4/RAGE paracrine signaling to promote melanoma transmigration. S100A4 also stimulates the production and secretion of MMP-9, which likely aids in degrading the extracellular matrix to promote transmigration [59]. A neutralizing monoclonal antibody targeting S100A4, 5C3, has been shown to prevent endothelial cell migration of melanoma cells in an immunodeficient mouse xenograft model [59], thus additional research on the clinically relevant efficacy of targeting S100A4 should be explored.

Pleckstrin homology domain-containing family A member 5 (PLEKHA5) is a recently described candidate to emerge from integrated comparisons of clinical melanoma samples and cell lines with a "brain homing" phenotype [60]. High PLEKHA5 expression in melanoma patients was associated with decreased brain metastasis-free survival, which is defined as the elapsed time from diagnosis of first 
distant metastasis to the diagnosis of brain metastasis. PLEKHA5 silencing decreased melanoma cell survival and inhibited transmigration through an in vitro BBB model, suggesting that PLEKHA5 plays a role in viability and extravasation into the brain parenchyma. It will be interesting to determine the mechanism by which PLEKHA5 mediates intracranial extravasation and whether it is important for melanoma brain metastasis formation in vivo.

Recently, bidirectional astrocyte-melanoma signaling has been shown to reciprocally stimulate an increase in the invasiveness of melanoma cells. Brain-metastasizing melanoma cells stimulate astrocytes to express the pro-inflammatory IL-23 cytokine resulting in IL-23-mediated stimulation of melanoma cells to secrete matrix metalloproteinase 2 (MMP2) [61]. MMP2 production increases extravasation by degrading collagen type IV, a major component of the extracellular matrix (ECM) surrounding the brain endothelial cells [61]. Increased MMP2 secretion via IL-23 signaling may be mediated through signal transducer and activator of transcription 3 (STAT3) [62] as STAT3 activity regulates MMP2 expression and human brain metastatic melanoma cells and tissue biopsies show increased STAT3 activity as compared to cutaneous melanoma cells and extracranial lesions [63]. Up-regulation of MMP2 has been previously tied to melanoma invasion as it was shown to be upregulated in highly metastatic human melanoma cell lines and strong MMP2 expression significantly correlates with advanced metastatic disease and worse overall survival $[64,65]$. In vitro BBB models have demonstrated that MMP2 expression influences transmigration of melanoma cells across human brain endothelial cells and additionally supports a role for other MMPs (e.g., MMP7, 10, 11, 13) in potentially mediating degradation of the extracellular matrix to facilitate extravasation [66].

TGF- $\beta 2$, discussed above in regulating melanoma brain tropism, also controls the permeability of endothelial cell monolayers, and may thus influence melanoma cell extravasation as well. TGF- $\beta 2$ was shown to decrease endothelial barrier tightness in in vitro BBB assays by regulating MMP secretion and down-regulating endothelial tight junction proteins [67]. Studies to determine whether TGF- $\beta 2$ functions similarly to support and enable transmigration of melanoma cells across the BBB in vivo have not been reported.

These mechanisms highlight the incredibly complex nature of melanoma cell interactions with the brain endothelium. Additional studies detailing how brain-tropic melanoma cells transmigrate across the endothelial BBB are underway, aided by the development of more refined in vitro BBB models [68], and will likely reveal diverse and complex mechanisms that may enable additional targeting of the process of extravasation during the establishment of brain metastases.

\subsection{Perivascular Positioning and Growth by Vessel Co-Option}

The successful establishment of transmigrated melanoma cells as metastases is dependent upon their ability to secure necessary access to the microvasculature by maintaining perivascular localization and stimulating angiogenesis. Transmigrated melanoma cells gain access to the blood supply in two ways-persistent close contact to microvessels and perivascular growth by vessel co-option [9]. Kienast et al. noted that melanoma cells that had extravasated, but lacked intimate association with the abluminal side of the microvasculature, failed to proliferate and thus regressed [9]. Evidence for the high degree of proficiency that melanoma cells exhibit for vascular co-option has been observed in studies detailing the histomorphological characteristics of brain metastases in humans. When compared with lung, breast, colorectal, and kidney cancers, vascular co-option is most commonly observed in melanoma metastases [69]. Unfortunately, the mechanisms whereby brain metastastic melanoma cells secure necessary metabolites through vascular co-option and angiogenesis are still poorly understood. However, many of the aforementioned molecules involved in extravasation have also been shown to play roles in concomitantly fueling vessel co-option. For instance, Cx26 is also implicated in vessel co-option during melanoma metastasis to the brain [50]. STAT3 activation promotes brain metastasis by stimulating vascular remodeling through increased expression of basic fibroblast growth factor (bFGF), vascular endothelial growth factor (VEGF), and MMP-2 [63,70]. S100A4 overexpression in M21 melanoma cells simulates tumor vascularization 
in human melanoma xenograft models in addition to inducing transmigration [59]. Secretion of S100A4 was shown to synergize with VEGF to strongly promote angiogenesis and enable tumor growth [59]. Kienast et al. noted that the human melanoma cell line they injected intracardially, MDA-MB-435, lacked VEGF-A expression, suggesting that other mechanisms of vessel co-option and angiogenesis may be present and utilized by melanoma cells. A recent analysis of angiogenesis-related gene expression in human brain melanoma metastases documented a more than 50-fold increase in C-X-C motif chemokine ligand 10 (CXCL10), carcinoembryonic antigen related cell adhesion molecule 1 (CEACAM1), platelet and endothelial cell adhesion molecule 1 (PECAM1), cluster of differentiation 117 (CD117/KIT), collagen type IV alpha 2 (COL4A2), collagen type I alpha 1 (COL1A1), and heparan sulfate proteoglycan 2 (HSPG2) [71]. However, to what extent these genes contribute to neovascularization in melanoma brain metastases formation will require additional studies. Interestingly, the phosphatidylinositol-4,5-bisphosphate 3-kinase (PI3K)-protein kinase B (PKB/AKT) pathway, discussed in more detail in the following section, impacts vascular co-option and angiogenesis via its role in regulating VEGF, hypoxia-inducible factor 1-alpha (HIF1 $\alpha$ ), and angiopoietin-2 (ANG2) [72-75].

\section{AKT Signaling and Melanoma Brain Metastasis}

Aberrations that lead to over-activation of the PI3K/AKT signaling pathway are some of the most common events in human cancer [76]. In melanoma, oncogenic alterations of this pathway are observed in up to $70 \%$ of patient tumors and are associated with disease progression [77-79]. The PI3K/AKT pathway is an important regulator of cell cycle progression and therefore is a frequent contributor to cellular transformation when normal function is compromised via genetic or epigenetic modifications [80]. Conventional activation of the pathway is initiated at the cell surface by the phosphorylation of receptor tyrosine kinases (RTKs) in response to mitogen stimulation. This event induces the recruitment of phosphoinositide-3-kinase regulatory subunit 1 (PIK3R1) and phosphatidylinositol 3-kinase (PI3KCA), which form a heterodimer to produce PI3K at the plasma membrane. Here, PI3K phosphorylates phosphatidylionositol-4,5-bisphosphate (PIP2) to phosphatidylinositol-3,4,5,triphosphate (PIP3), a phospholipid that attracts and binds the serine-threonine-specific kinase AKT (Protein Kinase B). A subsequent conformational change in AKT permits its phosphorylation and activation by 3-phosphoinositide-dependent protein kinase 1 (PDK1) and mammalian target of rapamycin complex 2 (mTORC2) [81].

AKT is a major signaling hub that executes a myriad of biological responses including transcription, glucose metabolism, cell migration, cell proliferation, apoptosis, and angiogenesis [82]. Various mechanisms of PI3K/AKT hyperactivation have been described in the melanoma literature, including RTK amplification, activating mutations in and increased gene expression of PI3KCA, as well as genomic amplification and activating mutations in AKT [76,83-85]. However, the most common mechanism by which the PI3K/AKT pathway acquires hyperactivity is via inactivation or deletion of phosphatase and tensin homolog deleted on chromosome 10 (PTEN). PTEN is a lipid phosphatase that antagonizes the function of PI3K through dephosphorylation of PIP3; the conversion of PIP3 to PIP2 diminishes recruitment of AKT to the plasma membrane and suppresses AKT phosphorylation [86]. Ten to thirty percent of melanomas are subject to loss, mutation, or epigenetic silencing of PTEN [87], which results in increases in the level of phospho-AKT (P-AKT).

Although evidence that the PI3K/AKT pathway plays a role in melanoma initiation has been demonstrated in functional experiments (reviewed in [88]), studies comparing the levels of PTEN in primary versus metastatic melanomas suggest that PTEN inactivation, the predominant driver of aberrant PI3K/AKT activity in melanoma, is a late event $[89,90]$. Indeed, the transformation of normal nevi to melanoma in situ, and from melanoma in situ to metastasis, is marked by a progressive accumulation of P-AKT. Primary melanomas with robust P-AKT expression also correlate with a worse prognosis $[77,91]$. Furthermore, Govindarajan et al. discovered that over-expression of AKT in a radially growing melanoma cell line conferred an invasive, vertical growth phenotype when 
implanted in mice [92]. These studies implicate PI3K/AKT over-activation as a facilitator of melanoma progression and metastasis.

As advances in our understanding of PI3K/AKT hyperactivity in melanoma progression and metastasis continue to be made, many studies have shifted focus to brain tropism, the results of which are reshaping the way we think about the PI3K/AKT pathway and melanoma brain metastasis. Several studies that emphasize the temporal and spatial dynamics of PI3K/AKT activation during melanoma metastasis have highlighted the importance of PI3K/AKT hyperactivity in metastasis to the brain. An integrated analysis of patients with $\mathrm{BRAF}^{\mathrm{V} 600}$ - or NRAS-mutated, and PTEN loss stage IIIB/C melanomas, found that PTEN loss corresponded to a shorter time to brain metastasis and reduced overall survival in $\mathrm{BRAF}^{\mathrm{V} 600}$-mutated melanomas [93]. Immunohistochemical analyses of patient-matched brain and extracranial melanoma metastases by Niessner et al. also showed that PTEN was downregulated and P-AKT was upregulated in brain metastases, whereas the opposite effect was true in extracranial metastases [94]. A similar study revealed that although P-AKT levels between patient-matched brain, lung, or liver metastases and their corresponding regional metastases did not differ, there was a significant difference in P-AKT levels between distant metastatic sites, with the highest P-AKT levels residing in brain metastases [78]. A follow-up study using DNA, RNA, and protein-based analyses designed to better understand the molecular pathogenesis of melanoma brain metastases found that brain metastases exhibited specific molecular patterns distinct from extracranial metastases. Specifically, brain metastases displayed a PI3K/AKT activation signature as assessed by P-AKT levels and activation of glycogen synthase kinase- $3 \alpha / \beta(\mathrm{GSK} 3 \alpha / \beta)$ and proline-rich Akt substrate of $40 \mathrm{kDa}$ (PRAS40), downstream effectors of AKT. However, results of these analyses did not yield a conclusive rationale to account for these observations as no copy number gains or mutations of PIK3CA or AKT were found in brain metastasis-only tissue from matched samples. Fewer copies of PTEN were noted in $20 \%$ of brain metastases compared with extracranial metastases, nevertheless, neither reverse phase protein array (RPPA) or IHC revealed any decrease in PTEN expression between matched samples [95]. These results highlight the complex relationship between PTEN loss and AKT activation.

One recent in vivo study demonstrated that AKT activation is an important contributor to melanoma lung and brain metastasis. Using an autochthonous model of melanoma, Cho et al. demonstrated an important role for AKT1 activation on the incidence of brain metastasis in the presence or absence of Pten. In vivo experiments showed that when oncogenic alterations of

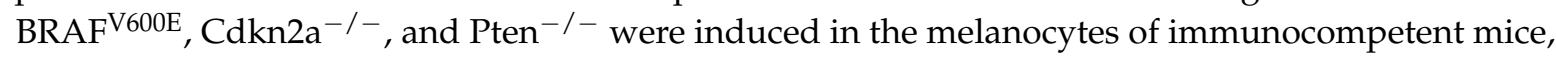
melanomas were generated in $100 \%$ of animals but fewer than $10 \%$ of the animals developed metastases. However, when a constitutively active form of AKT1 was expressed in this context nearly $80 \%$ of the animals developed brain metastases. Furthermore, RPPA analyses demonstrated differential gene expression and activation signatures in mTOR signaling pathway components between tumor samples with activated AKT1 versus Pten loss [96]. These findings indicate that the downstream activation profile of AKT1 does not mirror that of Pten loss. It is possible that the stimulation of different AKT isoforms may yield distinct cellular responses. The consequence of AKT2 or AKT3 (the predominantly active isoform in melanoma) [91] activation in this context is currently under investigation.

The PI3K/AKT pathway is linked to several later steps of melanoma metastasis and has been shown to regulate cell adhesion, extravasation, degradation of extracellular matrix proteins, and angiogenesis. These mechanisms include signaling between the PI3K/AKT pathway and CCR4, HSPE (heparanase), VEGF, STAT3, or Cx43. Molnár et al. recently showed that adhesion of melanoma cells to the brain endothelial cells requires PI3K activity, as its inhibition impaired melanoma cell adhesion and the early phase of transmigration [13]. CCL22, a ligand for CCR4, was found to increase P-AKT in primary-derived cells but decrease P-AKT in brain-derived cells, although the biological rationale behind these antagonistic responses or how the responses are orchestrated are not clear [19]. The increased invasiveness of melanoma cells into the brain tissues of brain slice models through the action of HSPE is at least partially attributed to the ability of HSPE to stimulate 
the PI3K/AKT pathway [43,97]. Inhibition of PI3K reduces melanoma cell transmigration through human umbilical vein endothelial cells (HUVECs), suggesting that this process is mediated through the PI3K/AKT signaling hub [73]. AKT also phosphorylates Ser369 and Ser373 on Cx43 [98], and while the consequence of this event in the context of melanoma biology remains to be determined, $\mathrm{Cx} 43$ promotes melanoma brain colonization through enhancement of cell extravasation and co-option of blood vessels [50]. Similar to $\mathrm{Cx} 43$, the cytokine and growth factor-dependent transcription factor, STAT3, has shown interconnectivity to the PI3K/AKT pathway in transformed murine cells, although many details of this complex interactive network have yet to be elucidated [99].

The microenvironment also appears to influence the gene expression patterns of melanoma cells present in the brain. In an in vitro study, human metastatic melanoma cells were assessed for PI3K/AKT activity and cell invasion after exposure to conditions that simulate the brain microenvironment. Patient-matched brain and extracranial metastases were immersed in astrocyteor fibroblast-conditioned medium. Cells exposed to astrocyte-conditioned medium responded by elevating levels of P-AKT and increasing invasiveness; this was not observed for cells exposed to fibroblast-conditioned medium [94]. In an impressive illustration of the power of the brain tumor microenvironment to influence the transcriptome of cancer cells, Park et al. used competitive cross-species hybridization of microarray experiments to highlight the ability of the brain microenvironment to dictate the transcriptional profiles and phenotypes of cancer cells. In this study, breast, colon, lung, or melanoma cells were transplanted into the brains or skin of immunodeficient mice. Tumors were later excised and the mRNA signatures of the human cancer cells analyzed. While 4213 genes significantly differed among melanomas transplanted subcutaneously, reflective of the intrinsic genetic differences between cancer types, only 21 genes differed among tumors transplanted into the brain. These experiments highlight the ability of the brain microenvironment to override cell-specific transcriptomes and execute radical reprogramming of invading cells [100].

A recently discovered, non-cell-autonomous mechanism by which the brain microenvironment stimulates the PI3K/AKT pathway is through astrocyte-derived exosomes that deliver PTEN-targeting miRNAs to melanoma cells. Zhang et al. discovered that PTEN-targeting miRNAs, previously determined to be encoded by the miR-17-92 allele [101-104], are excreted from brain astrocytes in exosomes, thereby mediating an intercellular silencing of PTEN and concomitant activation of PI3K/AKT in metastatic melanoma cells. Silencing of miR-17-92 in astrocytes, or inhibiting exosome secretion, rescued PTEN loss in melanoma cells and suppressed brain metastasis [105]. These experiments demonstrate how the brain milieu generates temporal and reversible epigenetic alterations in melanoma cells, thereby influencing their metastatic potential.

Substantial evidence exists that over-activation of the PI3K/AKT pathway is a causal factor in melanoma brain metastasis through both tumor cell autonomous and non-cell-autonomous mechanisms. Furthermore, alterations occur in many different members of this pathway in multiple cancer types [76]. The studies discussed here emphasize the numerous channels of interconnectivity to other signaling pathways, and demonstrate that we lack a complete understanding of how these modifications translate to different but widespread molecular changes that promote melanoma brain metastasis. The elucidation of this network will allow the identification of key pathway nodes that represent potential therapeutic targets to disrupt the process of melanoma brain metastasis.

\section{Animal Models of Melanoma Brain Metastasis}

There is a strong need to develop experimental models that accurately mimic the human disease both at the molecular and cellular levels such that more effective therapeutic strategies to prevent, delay, and treat melanoma brain metastases can be developed. Melanoma brain metastases have been successfully generated following transplantation of melanoma cells into immunodeficient mice (Figure 2a) [70,106-108]. Studies that introduce melanoma cells subcutaneously have the advantage of being able to recreate and analyze the full range of metastatic events necessary for the development of brain metastases from the primary tumor $[19,106,109]$. However, these models often have a long 
latency and require excision of the primary tumor followed by serial passage of the tumor cells in vivo to derive cell lines that reproducibly generate brain metastases.

Another method used to study melanoma brain metastasis is through injection of melanoma cells via the left cardiac ventricle or common carotid artery $[36,63,70,108-110]$. The direct introduction of cells into the circulation reduces disease latency and produces a high incidence of brain metastases. A disadvantage of this method is that early steps in the metastatic cascade are bypassed, and therefore this method is primarily useful for studying BBB extravasation and brain colonization. Direct injection of melanoma cells into the brain or the cisterna magna of immunodeficient mice has also been successfully employed to generate viable tumors that disperse and proliferate in the brain $[107,111]$. However, while this method is useful for assessing brain colonization and angiogenesis, it does not allow full analysis of the multi-step process of metastasis.

In immune-competent models, melanoma cells must evade the immune system during disease progression and therefore these models more accurately mimic the human disease. In the metallothionein (MT)/ret transgenic model, the human ret transgene is driven by the mouse MT promoter-enhancer, which activates MAPK signaling and promotes the development of spontaneous melanomas; a subset of these mice develop metastases of the brain and other distal sites $[112,113]$. The ret transgene system has subsequently been used to develop a spontaneous model of melanoma brain metastasis through the use of transplantable cells. Schwartz et al. utilized a melanoma cell line derived from ret-generated tumors and performed subcutaneous injections into syngeneic C57BL/ 6 mice to grow primary tumors that eventually metastasized to the brain in nearly $75 \%$ of mice [112,114]. However, alterations in RET have not been reported to occur in human melanomas [112].

The introduction of syngeneic murine melanoma cells via intracardiac injection in an immunocompetent model also has been performed and shown to produce brain metastases. In a study designed primarily to characterize brain metastasis growth patterns using magnetic resonance imaging, Morsi et al. injected murine B16F10 melanoma cells into the left cardiac ventricle of C57BL/ 6 mice. Contrary to the intracarotid artery method of injection, left ventricle injections allow cells to circulate freely within the vascular system, an approach that permits cells indiscriminate access to all major organs. This is a useful technique to determine the proclivity of a specific cell line to favor particular sites of metastasis. Brain metastases in this experiment were produced in approximately one quarter of the mice and with rapid onset [115]. However, as with left ventricle injections in immunodeficient mice, early steps in metastasis are bypassed. This study also demonstrated a propensity of B16F10 melanoma cells to seed and proliferate other extracranial sites.

Recently, an immune-competent autochthonous model of melanoma brain metastasis was developed based on the avian retroviral replication-competent ALV LTR splice acceptor (RCAS)/tumor virus A (TVA) system, whereby ectopic expression of the avian TVA receptor is expressed in melanocytes under control of the dopachrome tautomerase (DCT) promoter. Avian cells that produce an RCAS virus carrying an oncogene of interest are subcutaneously injected into DCT-TVA mice. The virus targets melanocytes and the delivered oncogene is permanently integrated into host DNA for long-term ectopic gene expression. This model also utilizes floxed alleles in melanoma-relevant genes to express $\mathrm{BRAF}^{\mathrm{V} 600 \mathrm{E}}$, inactivate the $C d k n 2 a$ locus, and inactivate Pten, via delivery of a second virus that carries Cre recombinase. Cho et al. used this model to generate melanoma in 100\% of mice and brain metastases in $79 \%$ of mice through expression of a constitutively active form of AKT1 in this context [96]. This system offers a reproducible method whereby primary tumors and brain metastases are produced quickly and reliably using specific combinations of oncogenic alterations commonly found in human melanoma. Other oncogenes of interest can also be quickly tested for their roles in melanoma brain metastasis based on physiologically relevant genetic mutations that occur in the human disease.

Non-murine preclinical animal models provide additional options to study melanoma brain metastasis. Because malignant transformation displays some parallels to the physiology of embryonic 
cells, Busch et al. set out to explore the effects of an embryonic-rich environment on the invasiveness of human melanoma cells in the brain. To accomplish this objective, the chicken embryo was chosen as a model in which to perform xenotransplantation experiments (Figure 2b). Melanoma cells injected into the rhombencephalon of embryos were found to reproduce the invasive characteristics of the human disease. This model offers the potential of studying the disease spread of multiple human melanoma cell lines. Embryos are easily accessible and tumor spread is rapid. However, the clinical relevance of malignant cell behavior in an environment saturated by growth-promoting undifferentiated cells remains unclear. Furthermore, while this method is useful for assessing brain colonization and angiogenesis, it does not allow full analysis of the multi-step process of metastasis.

In recent years the zebrafish has emerged as a useful animal model to study cancer due in part to the transparency of its embryos and the ability to map the fate of single cells with unprecedented detail through high-resolution imaging. For this reason, this model is an attractive candidate to assess the spatio-temporal dynamics of disease spread. In order to perform a comprehensive quantitative analysis of metastatic biology, Heilmann et al. used a transgenic capser zebrafish model with the genotype $B R A F^{V 600 E} ; \mathrm{p53}^{-/-} ; \mathrm{mitfa}^{-/-}$, a strain devoid of melanocytes. Fish were injected with a plasmid that uses separate mitfa promoters to drive expression of microphthalmia-associated transcription factor (MITF) and enhanced green fluorescence protein (EGFP). Upon in vivo rescue of MITF expression, patches of EGFP-positive melanocytes formed, a subset of which underwent transformation. Stable cell lines were generated from primary tumors, one of which (ZMEL1) was transplanted subcutaneously into irradiated adult casper fish, or the vasculature of casper embryos (Figure 2c). In both circumstances, primary tumors and subsequent metastases to multiple sites including the head were observed within two weeks [116]. Advantages of this model include the rapid generation of progeny, the ability to track the fate of single metastatic cells that quickly spread, and the potential to use gene editing of cell lines to perform genome-wide in vivo screens to more clearly define the contribution of a specific gene in metastasis. However, similar to the chicken embryo model, experiments in the growth-promoting environment of the fish embryo lack physiological relevancy. Likewise, these experiments require that adult fish are irradiated to compromise adaptive immunity prior to the introduction of melanoma cells.

a

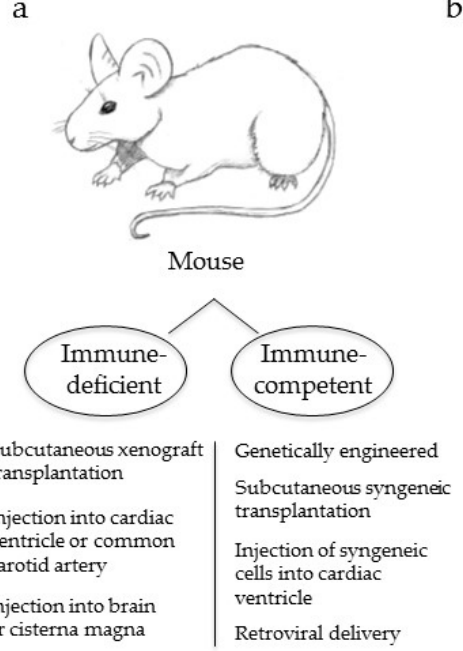

b

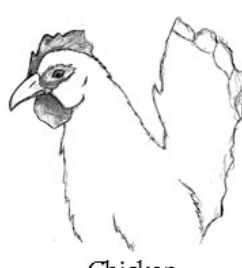

Chicken

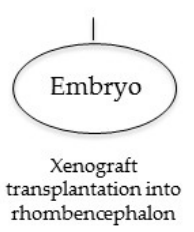

c
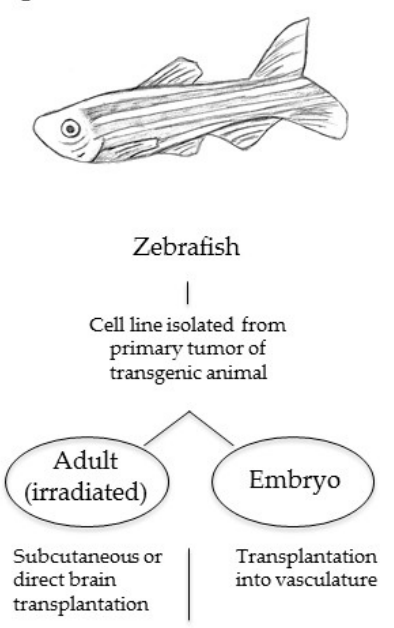

Figure 2. Animal models used to investigate melanoma brain metastasis. (a) Immunodeficient and immunocompetent mouse models; (b) Chicken embryo model; (c) Zebrafish adult and embryo models.

Current animal models of melanoma brain metastasis have made advances in our understanding of the melanoma cerebrotropism but many questions remained unanswered. Improvements in present models and the development of new models are needed to increase our understanding of the biology of melanoma brain metastasis. This will require sophisticated models that minimize the fundamental limitations imposed by differences in species biology, and maximize the ability to mimic 
the heterogeneity of the human disease in a relevant microenvironment. Goals will be to identify useful biomarkers of brain metastasis, interrogate and accurately describe molecular mechanisms of these processes, assess the efficacy of existing and experimental therapeutics, as well as develop new effective treatment strategies. In vivo models capable of identifying how and why brain metastasis occurs will provide a foundation upon which important new scientific breakthroughs and treatment strategies can be translated to the clinic for improved patient care.

\section{Melanoma Brain Metastasis Therapies}

Brain metastases are a major complication of metastatic melanoma and are responsible for up to half of all melanoma deaths [117-120]. Among all cancers that frequently metastasize to the brain, including breast, lung, colon, and renal, melanomas have the highest frequency for colonizing this organ [121-124]. Between $6 \%$ and $43 \%$ of melanoma patients present with brain metastases at stage IV diagnosis and nearly $75 \%$ of autopsy reports identify CNS involvement $[120,125,126]$, as tumor burden in terminal patients is often higher than clinically realized. Brain metastasis bodes very unfavorably for prognosis in melanoma and overall survival time for patients with intracranial metastases ranges between 4 and 9 months after diagnosis [118,126,127]. A graded prognostic assessment (GPA) was introduced by Sperduto et al. to systematically and more accurately determine the prognosis of patients with brain metastases. The diagnosis-specific GPA considers age, Karnofsky performance score (KPS: a measure of the ability of a patient to perform ordinary tasks), extracranial metastases, and the number of brain metastases [128]. A melanoma-specific GPA was revised recently and prognosis was determined to be based primarily on KPS and the number of brain metastases, with a low KPS score and more total brain metastases indicative of a poor prognosis (median OS of 3.4 months) and a higher KPS with fewer metastases showing a better prognosis (median OS of 13.2 months) [129]. However, with the advance of targeted therapies such as BRAF and MEK inhibitors and immune checkpoint inhibitors (discussed in detail below), the utility and accuracy of the Sperduto GPA for determining the prognosis of patients with melanoma brain metastases will be altered and thus require additional revisions to remain a useful prognostic tool [130].

The morbidity and mortality associated with melanoma brain metastases are most often attributed to hemorrhage and increased intracranial pressure. Among all brain malignancies, melanoma brain metastases have the highest risk of hemorrhage, with $27 \%-40 \%$ of all intracranial lesions showing active hemorrhage on neuroimaging and up to $71 \%$ of patients with melanoma brain metastases showing evidence of prior hemorrhage by histopathology [131,132]. In addition to hemorrhage, brain metastases are associated with other complications such as hydrocephalus from obstructed flow of cerebrospinal fluid and local mass effect by tumor expansion [124]. These complications place the patient at risk for increased intracranial pressure and commonly manifest as headaches, nausea, mental status change, vomiting, cranial nerve palsies, visual deficits, hemiparesis, and sensory loss [124,131]. Focal and generalized seizures are also common sequelae of brain metastases and further add to the morbidity of this complication.

Current clinical therapy for melanoma brain metastasis can be divided into three broad categories: palliative, definitive, and investigational [124,133]. Palliative care includes steroids to reduce inflammation caused by hemorrhage and edema, anticonvulsants to combat seizures secondary to the metastatic lesion, and anticoagulants to prevent post-operative thromboembolic disease. Definitive therapy includes radiation, either whole brain radiation therapy or stereotactic radiosurgery (SRS), surgical resection, and chemotherapy $[127,134]$. Investigational therapies encompass the recently approved targeted and immune therapies, which are beginning to show great promise [135-137].

General recommendations for a particular therapy, which take into account the estimated prognosis of the patient and overall aim of treatment, are based on several criteria, including the size of the brain metastasis, the location of the brain metastasis, and the presence of other brain metastases $[124,136,138,139]$. Other important factors include age, the presence and/or extent of 
extra-cranial metastases, KPS, and overall health of the patient [136]. The median overall survival of brain metastasis patients opting out of definitive therapy is approximately $1-2$ months $[120,140]$.

\subsection{Surgery}

Surgical resection is an option if the metastasis is solitary or limited in number and located in a surgically accessible area [141]. Surgery may be recommended if the metastasis is symptomatic and/or requires a diagnosis but biopsy of an alternative area is not feasible [142-144]. Immediate tumor de-bulking, definitive targeting of the lesion, and histological and molecular characterization of resected tissues, while alleviating symptomatic mass effects of the tumor, are all advantages of surgical resection. Melanoma brain metastasis patients who are candidates for surgical resection and initially receive this treatment have a median overall survival of 9.83 months [118,145]. Patients with multiple melanoma brain metastases or disseminated carcinomatous cell spreading in the brain also known as "miliary metastases" are not surgical candidates and are recommended alternative therapies such as radiation. For patients who undergo surgical resection, post-operative radiation therapy in the form of SRS or whole brain radiation therapy (WBRT) is common [141,146,147].

\subsection{Stereotactic Radiosurgery}

Melanoma is notoriously radioresistant; however, radiation therapy is an integral part of the standard of care for patients with brain metastasis [144]. SRS is a targeted approach that involves the administration of a single fraction of ionizing radiation via several converging beams onto a targeted site. The delivery of high-dose, focally targeted radiation to a confined area has been demonstrated to minimize extraneous exposure and mitigate the undesired side-effects of radiotherapy [148,149]. Evidence-based guidelines from the American Society for Radiation Oncology recommend that SRS, rather than WBRT, be utilized to treat patients with limited brain disease [144]. SRS is most effective when treating patients who have small lesions numbering fewer than 3 [143] and confers a survival advantage for patients who are $\leq 50$ years of age [150]. Melanoma patients recommended to receive SRS and initially treated with this modality have a median overall survival of 7.69 months [118]. This OS for SRS has been corroborated recently ( 8.1 months) in a report that also devised novel risk scores for OS and intracranial failure [151]. Chowdhury et al. report a model to determine risk scores of OS based on performance status, extracranial disease status, number of lesions, and gender, thereby providing additional predictors for prognosis and treatment strategy [151]. Treatment of brain metastases with SRS will also benefit from considering and incorporating individual histologies into treatment plans, especially when used in combination with systemic therapies, as such studies will be instrumental in determining outcomes [144].

\subsection{Whole-Brain Radiation Therapy}

WBRT is untargeted over the entire brain and therefore has the potential to cause acute adverse effects, including cerebellar dysfunction and cognitive deterioration, which vary by duration and severity [152]. Despite the radioresistant nature of melanoma, WBRT is used when the number of brain metastases is such that it precludes a more targeted approach [140]. WBRT has been shown to prevent intracranial relapse, but has little impact on overall survival [149]. A prospective study by Aoyama et al. demonstrated that the use of WBRT with SRS did not improve the survival for patients with 1-4 intracranial lesions, as compared with SRS alone [149]. Patients receiving WBRT have a median survival of 3.86 months $[118,153]$. A recent study that systematically reviewed the outcomes reported in 73 articles published between 1995 and 2014 also showed that WBRT has no significant impact on overall survival, but that combining it with SRS improved the brain relapse rate [153]. Because of the promise that targeted or immune-based therapies have shown (discussed below), combining them with SRS may eliminate the need for WBRT [153]. 


\subsection{Chemotherapy}

Standard chemotherapy for metastatic melanoma in the brain has not proven effective. Temozolamide, fotemustine, and thalidomides are used clinically in combination or alone but have very low response rates ranging between $7 \%$ and $10 \%$ and patients receiving chemotherapy alone to treat melanoma brain metastases have a median overall survival of 4.64 months [118,153-156]. Presumably this is due to the low intracranial activity of chemotherapeutics based on their inability to bypass the BBB.

\subsection{Targeted Therapies}

Targeted therapies include small molecules that inhibit the hyper-activated MAPK signaling pathway or antibodies that enhance the immune system response, but these are not currently standard of care for treatment of melanoma brain metastasis, largely because of the presupposed difficulties of bypassing the BBB. Until recently, melanoma patients with active brain metastases have been excluded from clinical trials that test their efficacy. However, several new studies have demonstrated that they are at least partially efficacious for treating intracranial lesions and are thus being considered for further investigation [135,137]. A systematic review of current clinical trials identified survival outcomes of melanoma brain metastasis patients who were treated with MAPK inhibitors and/or immune-based checkpoint blockade and reported that both have evidence of clinical activity and may increase OS in these patients [137].

\subsection{MAPK Pathway Inhibitors}

Approximately $40 \%-50 \%$ of melanoma patients have activating mutations in BRAF at valine 600 $\left(90 \%\right.$ are $\left.\mathrm{BRAF}^{\mathrm{V} 600 \mathrm{E}}\right)$ and another $15 \%-25 \%$ have mutations in the neuroblastoma RAS viral oncogene homolog (NRAS), and either alteration results in constitutive activation of the MAPK pathway [156]. Thus, inhibitors of the MAPK pathway are therapeutically relevant to a significant number of patients with metastatic melanoma. Inhibitors of mutant $\mathrm{BRAF}^{\mathrm{V} 600}$ have garnered much attention based on their impressive efficacy in treating metastatic melanoma, as rapid, systemic responses are frequently seen within weeks of the onset of treatment. These findings have sparked new studies designed to address the efficacy of $\mathrm{BRAF}^{\mathrm{V} 600}$ inhibitors against intracranial lesions. Two BRAF ${ }^{\mathrm{V} 600}$ inhibitors are currently approved for clinical use: vemurafenib and dabrafenib. Intracranial activity was shown for both based on two small phase II trials $[157,158]$; however, no study with survival as the primary endpoint was conducted initially. Most recently, a systematic examination of twenty-two studies that reported median OS data for 2153 melanoma patients concluded that treating melanoma patients who have brain metastases with $\mathrm{BRAF}^{\mathrm{V} 600}$ inhibitors (or immunotherapy, discussed below) may improve survival [137]. Spagnolo et al. calculated a median OS of 7.9 months for patients treated with BRAF inhibitors, relative to the historical survival of 6.2 months for patients with metastatic melanoma overall and 2.2-4.7 months for patients with intracranial metastases [137]. In addition, evidence for the importance of treating patients with effective $\mathrm{BRAF}^{\mathrm{V} 600}$ inhibitors has come from several reports that have determined that inhibiting $\mathrm{BRAF}^{\mathrm{V} 600}$ significantly prolonged the time between the initial metastatic melanoma diagnosis and the subsequent brain metastasis diagnosis [159] and also lowered the incidence of brain metastasis formation [160].

Vemurafenib was the first $\mathrm{BRAF}^{\mathrm{V} 600}$ inhibitor to demonstrate an increase in OS for patients as compared with dacarbazine [161], a cytotoxic DNA-alkalylating agent previously used regularly to treat metastatic melanoma. Vemurafenib has good tolerability and antitumor activity; however, early studies excluded patients with active brain metastases. More recently, OS and progression-free survival (PFS) was reported for 24 patients treated with vemurafenib who had symptomatic, non-resectable intracranial disease [162]. Dummer et al. found that $37 \%$ of patients showed a greater than $30 \%$ regression in brain metastases and 16\% showed a partial response, with a median PFS of 3.9 months and median OS of 5.3 months [162]. An additional study that included 27 patients with intracranial disease treated with vemurafenib reported extracranial and intracranial response rates of $71 \%$ and $50 \%$, respectively [163]. The median intracranial PFS was 4.6 months and median OS was 7.5 months, 
thus demonstrating that vemurafenib is highly active in mutant BRAF melanoma, with intracranial activity evident. These studies demonstrated an intracranial regression of melanoma metastases, suggesting that vemurafenib is at least partially able to penetrate the BBB. A small study including six patients treated with vemurafenib twice daily was performed to determine whether vemurafenib was able to cross the BBB. Sukji-Dupre et al. measured cerebrospinal fluid (CSF) concentrations of vemurafenib and compared them to plasma concentrations [164]. They reported the mean ratio of CSF/plasma concentration as only $0.98 \% \pm 0.84 \%$, suggesting poor penetration of the BBB by vemurafenib [164]. Additional studies with larger cohorts are needed to determine if this low level of BBB penetration is accurate. However, the intracranial response reported by Harding and Dummer suggests that either low levels of vemurafenib in the CSF are effective or that control of extracranial disease may affect intracranial melanoma metastases progression. Alternatively, establishment of brain metastases by melanoma cell transmigration through the endothelium may compromise the $\mathrm{BBB}$, enabling vemurafenib to more effectively penetrate the BBB, resulting in tumor regression. These highlighted studies demonstrate the potentially therapeutic benefit of vemurafenib for patients with $\mathrm{BRAF}^{\mathrm{V} 600}$ brain metastases, but also reveal the critical need for additional clinical studies that are designed to examine vemurafenib treatment alone or in combination with other therapies such as MEK inhibitors (discussed below).

Dabrafenib, another $\mathrm{BRAF}^{\mathrm{V} 600}$ inhibitor, has also shown therapeutic benefit for melanoma patients with brain metastases. A pilot study investigated the effect of dabrafenib treatment in patients with melanoma brain metastasis and reported that 9 out of 10 patients showed brain tumor regression [165]. An additional study, with a larger cohort of 172 patients, reported a response rate of $39.2 \%$ with dabrafenib treatment of patients with the $\mathrm{BRAF}^{\mathrm{V} 600 \mathrm{E}}$ mutation who had no prior treatment of their brain metastases [157]. Long et al. reported a median PFS of 4.0 months and a median OS of 8.3 months [157]. A more recent analysis that focused on comparing the response of both intraand extra-cranial metastatic melanoma to dabrafenib showed that both had high response rates and similar PFS [166]. Azer et al. corroborated the median PFS (4 months) and OS (9 months) [166] that was recorded previously by Long et al. [157]. To date, no studies have reported upon the ability of dabrafenib to penetrate the BBB in patients; however, dabrafenib distribution to the brain is also significantly limited by the BBB, though to a lesser extent than vemurafenib, as determined by in vitro transport assays and in vivo pharmacokinetic studies [167].

In a small study performed to determine why some melanoma brain metastases were poorly sensitive to vemurafenib, Harding et al. analyzed samples from 7 patients who were categorized as poorly sensitive (defined as greater than $20 \%$ tumor growth, new lesion formation, or less-than $50 \%$ tumor shrinkage for less-than 4 months). They used next-generation sequencing and found that tumors that were insensitive to vemurafenib contained co-occurring mutations that resulted in activation of the PI3K-AKT pathway [163]. This demonstrates that melanomas resistant to vemurafenib may be sensitive to combination therapies that target the PI3K-AKT pathway concomitantly with MAPK inhibition. However, only a small number of samples were analyzed and no clinical trials are currently being performed to evaluate PI3K/AKT inhibitors with or without BRAF inhibitors. However, additional clinical trials designed to test the efficacy of combination therapies that include inhibitors of the mitogen-activated protein kinase kinase (MEK), which is downstream of BRAF in the MAPK pathway, are currently underway (see Table 1). These include treatments with combinations of the MEK inhibitor, trametinib, with dabrafenib (clinical trials NCT02039947 \& NCT01978236), or vemurafenib with another MEK inhibitor, cobimetinib (clinical trial NCT02537600). An additional clinical trial is assessing the therapeutic outcome of treating brain metastases with dabrafenib and SRS (clinical trial NCT01721603). As of the publication date of this manuscript, these trials are either still recruiting or are currently evaluating whether combination therapies benefit patients with $\mathrm{BRAF}^{\mathrm{V} 600}$ brain metastases. The results from these investigations will hopefully bring about therapeutic improvements and an increased understanding of the efficacy of inhibiting the often hyper-activated MAPK pathway with the goal of improving the survival of patients with brain metastases. 
Table 1. Summary of clinical trials in progress for patients with metastatic melanoma ${ }^{1}$.

\begin{tabular}{|c|c|c|c|c|}
\hline Trial & Phase & Status & Primary Outcome Measured & Title \\
\hline NCT01721603 & II & Active, not recruiting & Safety/efficacy & $\begin{array}{l}\text { A Phase } 2 \text { Prospective Trial of Dabrafenib with Stereotactic Radiosurgery in } \\
\text { BRAF }{ }^{V 600 E} \text { Melanoma Brain Metastases }\end{array}$ \\
\hline NCT02115139 & II & Recruiting & 1-year survival rate & GEM STUDY: Radiation and Yervoy in Patients with Melanoma and Brain Metastases (GRAY-B) \\
\hline NCT01703507 & I & Active, not recruiting & Maximum tolerated dose ipilimumab & $\begin{array}{c}\text { Phase I Study of Ipilimumab Combined with Whole Brain Radiation Therapy or } \\
\text { Radiosurgery for Melanoma }\end{array}$ \\
\hline NCT02085070 & II & Recruiting & Response rate & MK-3475 in Melanoma and NSCLC Patients with Brain Metastases \\
\hline NCT02097732 & II & Recruiting & Local control rate & $\begin{array}{l}\text { Ipilimumab Induction in Patients with Melanoma Brain Metastases Receiving } \\
\text { Stereotactic Radiosurgery }\end{array}$ \\
\hline NCT02039947 & II & Recruiting & Intracranial response rate & $\begin{array}{l}\text { Study to Evaluate Treatment of Dabrafenib Plus Trametinib in Subjects with BRAF } \\
\text { Mutation-Positive Melanoma That Has Metastasized to the Brain }\end{array}$ \\
\hline NCT01378975 & II & Completed, no posts & Best overall response rate & A Study of Vemurafenib in Metastatic Melanoma Patients with Brain Metastases \\
\hline NCT01978236 & II & Recruiting & $\begin{array}{l}\text { Concentrations of dabrafenib \& } \\
\text { trametinib in metastases }\end{array}$ & $\begin{array}{l}\text { Dabrafenib/Trametinib, BRAF or BRAF AND MEK Pre-op with BRAF and MEK Post-op, } \\
\text { Phase IIB, Melanoma with Brain Mets, Biomarkers and Metabolites }\end{array}$ \\
\hline NCT02320058 & II & Recruiting & Clinical benefit rate & $\begin{array}{c}\text { A Multi-Center Phase } 2 \text { Open-Label Study to Evaluate Safety and Efficacy in Subjects with } \\
\text { Melanoma Metastatic to the Brain Treated with Nivolumab in Combination with Ipilimumab } \\
\text { Followed by Nivolumab Monotherapy (CheckMate 204) }\end{array}$ \\
\hline NCT01503827 & III & Recruiting & Distant intracranial failure & $\begin{array}{l}\text { Whole Brain Radiotherapy Following Local Treatment of Intracranial Metastases } \\
\text { of Melanoma (WBRTMel) }\end{array}$ \\
\hline NCT01644591 & III & Active, not recruiting & Time to local failure & $\begin{array}{l}\text { Trial to Compare Local Control and Neurocognitive Preservation after Initial Treatment with } \\
\text { Stereotactic Radiosurgery (SRS) versus Whole Brain Radiation Therapy (WBRT) for Patients } \\
\text { with }>3 \text { Brain Metastases from Melanoma }\end{array}$ \\
\hline NCT02460068 & III & Recruiting & Overall survival rate & $\begin{array}{c}\text { A Study of Fotemustine(FTM) vs. FTM and Ipilimumab (IPI) or IPI and Nivolumab in Melanoma } \\
\text { Brain Metastasis (NIBIT-M2) }\end{array}$ \\
\hline NCT02374242 & II & Recruiting & Intracranial response rate & Anti-PD 1 Brain Collaboration for Patients with Melanoma Brain Metastases (ABC) \\
\hline NCT02662725 & II & Completed, no posts & Overall survival rate & $\begin{array}{l}\text { Ipilimumab Combined with a Stereotactic Radiosurgery in Melanoma } \\
\text { Patients with Brain Metastases (IPI + RTS) }\end{array}$ \\
\hline NCT02308020 & II & Recruiting & $\begin{array}{l}\text { Complete response, partial response, } \\
\text { objective intracranial response rates }\end{array}$ & $\begin{array}{l}\text { A Study of Abemaciclib (LY2835219) in Participants with Breast Cancer, Non-small Cell Lung } \\
\text { Cancer, or Melanoma That Has Spread to the Brain }\end{array}$ \\
\hline NCT02681549 & II & Recruiting & Brain metastasis response rate & $\begin{array}{l}\text { Pembrolizumab Plus Bevacizumab for Treatment of Brain Metastases in Metastatic Melanoma or } \\
\text { Non-small Cell Lung Cancer }\end{array}$ \\
\hline NCT02621515 & II & Recruiting & Best overall response rate & Nivolumab in Symptomatic Brain Metastases (CA209-322) \\
\hline NCT02716948 & I & Recruiting & Incidence of serious adverse events & $\begin{array}{c}\text { Stereotactic Radiosurgery and Nivolumab in Treating Patients with Newly Diagnosed Melanoma } \\
\text { Metastases in the Brain or Spine }\end{array}$ \\
\hline NCT01904123 & I & Not yet recruiting & Maximum tolerated dose WP1066 & $\begin{array}{c}\text { A Phase I Trial of WP1066 in Patients with Central Nervous System (CNS) Melanoma and } \\
\text { Recurrent Glioblastoma Multiforme (GBM) }\end{array}$ \\
\hline
\end{tabular}


Table 1. Cont

\begin{tabular}{ccccc}
\hline Trial & Phase & Status & Primary Outcome Measured & Title \\
\hline NCT02452294 & II & Recruting & Intracranial disease control rate & Buparlisib in Melanoma Patients Suffering from Brain Metastases (BUMPER) \\
\hline NCT02537600 & II & Recruiting & $\begin{array}{c}\text { Complete or partial intracranial } \\
\text { response rate }\end{array}$ & $\begin{array}{c}\text { Vemurafenib and Cobimetinib Combination in BRAF Mutated Melanoma with } \\
\text { Brain Metastasis (CONVERCE) }\end{array}$ \\
\hline NCT02107755 & II & Recruiting & Progression-free survival rate & Stereotactic Radiation Therapy and Ipilimumab in Treating Patients with Metastatic Melanoma \\
\hline \multirow{2}{*}{ NCT01983124 } & II & Completed, no posts & Progression-free survival rate & Vemurafenib + Fotemustine to Treat Advanced Melanoma Patients with V600BRAF Mutation \\
Recurred While on Vemurafenib (BeyPro1)
\end{tabular}

${ }^{1}$ Trials either focus on melanoma brain metastasis or do not exclude patients with melanoma brain metastasis. 


\subsection{Immune-Based Therapies}

Immune-based therapies have yielded some promising results for the treatment of melanoma brain metastasis. High-dose (HD) interleukin-2 (IL-2), a cytokine-based immunotherapy, was the first immunotherapy to be used for patients with metastatic melanoma. HD IL-2 produces durable, complete remission for a small percentage of metastatic melanoma patients $(<10 \%)$ [168], but has been associated with severe toxicity and its efficacy against brain metastases is limited. A retrospective analysis of 15 stage IV melanoma patients reported that 2 with brain metastases had a complete response to HD IL-2 [169]. However, a more recent retrospective review of 7 patients with brain metastases reported progressive disease in all patients and a median OS of only 6.7 months [170].

Adoptive cell transfer (ACT) of tumor-infiltrating lymphocytes, which requires the harvesting of tumor-derived $\mathrm{T}$ cell lymphocytes from melanoma patients, followed by expansion (with or without genetic manipulation), and re-introduction of these cells into patients after lympho-depletion, demonstrated efficacy against melanoma brain metastases in one report [171]. Hong et al. reported that $41 \%(7 / 17)$ of patients who received ACT had a complete response and $35 \%(6 / 17)$ showed a partial response [172]. Despite these encouraging results, ACT treatment has been replaced by checkpoint inhibitors.

Checkpoint inhibitors are a new class of immune-based therapy that utilize antibodies against specific inhibitory T-cell molecules to increase the amplitude and duration of T-cell responses [173]. Currently, there are two that are approved for the treatment of melanoma metastasis: ipilimumab, a monoclonal antibody against cytotoxic T-lymphocyte-associated protein 4 (CTLA-4), and pembrolizumab or nivolumab, antibodies against programmed cell death protein 1 (PD-1) [174-176]. Patients with brain metastases who were treated with immune-based checkpoint blockade antibodies, reported in a systematic review of recent clinical trials that included 2153 patients, had a median OS of 7.0 months [137].

A phase II trial of ipilimumab, which included patients with symptomatic and asymptomatic brain metastases, found that $10 \%$ and $24 \%$ achieved partial response or stable disease, respectively. Median OS was 3.7 and 7 months, and 2-year OS was 10\% and 24\%, respectively [177]. Another phase II study was designed to evaluate ipilimumab combined with fotemustine, a chloroethyl-nitrosourea alkylating agent, for the treatment of patients with asymptomatic brain metastases. Half of all patients $(10 / 20)$ showed disease control with a median PFS of 4.3 months [178]. A retrospective review by Knisely et al. assessed survival in patients who received SRS in addition to other clinical therapeutics and reported that patients who received ipilimumab as part of their therapeutic regimen had a median OS of 21.3 months compared with 4.9 months for patients without ipilimumab. The 2-year survival rates were $47 \%$ and $20 \%$, respectively [179]. Several other studies also have reported a clinical benefit when ipilimumab was combined with other therapies, such as SRS [180-187].

Anti-PD-1 immunotherapies (pembrolizumab and nivolumab) have been evaluated for their efficacy in treating melanoma brain metastases, although the data is limited. One phase II clinical trial of patients with untreated or progressive melanoma brain metastases showed pembrolizumab activity in brain metastases with 4 of 18 patients responding to treatment. The drug also demonstrated an acceptable safety profile [188]. In a second phase II clinical trial of pembrolizumab for patients with asymptomatic melanoma brain metastasis, the drug was found once again to possess brain activity, with 4 of 14 patients exhibiting a partial response and progression-free survival in the range of 6 to 17 months [189]. Nivolumab likewise, appears to show activity against melanoma brain metastases. A retrospective study designed to analyze nivolumab efficacy in combination with SRS in patients with melanoma brain metastases reported a median overall survival of 12 months. The authors concluded that disease control and OS appeared to be extended for patients on nivolumab compared with patients on conventional therapies [190].

Although the benefits of recent therapeutic breakthroughs have improved clinical outcomes for patients with melanoma brain metastasis [135], substantial advances in this patient population remain elusive. Additional clinical trials will assess the efficacy of immunotherapies alone or in combination 
with other therapeutic intervention strategies against melanoma brain metastases. Several studies are underway including: NCT01703507, NCT02085070, NCT02097732, NCT02320058, NCT02460068, NCT02374242, NCT02662725, NCT02681549, NCT02621515, NCT02716948, and NCT02107755 (Table 1), the results of which will enhance our understanding of immunotherapy intervention as it relates to brain metastases and ultimately improve patient care.

\section{Conclusions}

Studies aimed at better understanding chemokine signaling, cell arrest in the brain microvasculature, extravasation, and vascular co-option have brought to light important molecules that may promote brain tropism and potentially reveal novel targets for therapeutic intervention. Many of the recently identified mechanisms exhibit links to the PI3K/AKT signaling pathway and in vitro and in vivo studies of PI3K/AKT pathway inhibition for brain metastatic melanoma have already begun. Using a pan-class I PI3K inhibitor (buparlisib), Niessner et al. demonstrated diminished AKT activity, decreased cell growth and proliferation, and increased apoptosis in numerous metastatic melanoma cell lines with various mutational profiles. Buparlisib is also able to cross the BBB and inhibited growth of melanoma brain metastases in nude mice [107]. Although these results are encouraging, many additional tests are required before buparlisib or other PI3K/AKT inhibitors can advance to clinical trials. A more thorough understanding of the role of the PI3K/AKT pathway as well as other signaling pathways in melanoma brain metastasis biology is still needed. Melanoma has the highest somatic mutational load of all solid tumor types [191], which makes understanding the intricate mechanisms of oncogenicity extremely complex. In addition, extrinsic factors contribute to melanoma brain tropism, such as the influence of the BBB and brain microenvironment on melanoma cell homing, extravasation, and genetic reprogramming. These complexities, combined with the difficulty of creating pharmaceuticals that are safe, effective, specific, and able to penetrate the BBB make the mission to develop improved treatments for these patients extremely difficult. Animal models of melanoma brain metastasis have become an integral component in the quest to overcome many of these challenges as they offer a conduit through which important discoveries may be translated to the clinic. As meaningful new discoveries are made, in vivo models will be used to validate findings. Modern targeted therapies and immunotherapies will continue to be tested in vivo and later tested in a broader range of more sophisticated and relevant animal models for efficacy against brain metastases; future therapeutic strategies based on current basic research will follow suit-all with the goal of improving melanoma patient survival.

Acknowledgments: We thank the members of the VanBrocklin and Holmen labs for critical review of the manuscript. We thank Rowan Arave and Stephanie Hardy for assistance with figures. This work was supported by Award Number 347651 from the Melanoma Research Alliance and R01 CA121118 from the National Cancer Institute (to Sheri L. Holmen). Funds were received to cover the costs to publish in open access.

Author Contributions: David A. Kircher, Mark R. Silvis, Joseph H. Cho, and Sheri L. Holmen jointly wrote the paper.

Conflicts of Interest: The authors declare no conflict of interest.

\section{References}

1. Nguyen, D.X.; Bos, P.D.; Massague, J. Metastasis: From dissemination to organ-specific colonization. Nat. Rev. Cancer 2009, 9, 274-284. [CrossRef] [PubMed]

2. Maman, S.; Edry-Botzer, L.; Sagi-Assif, O.; Meshel, T.; Yuan, W.; Lu, W.; Witz, I.P. The metastatic microenvironment: Lung-derived factors control the viability of neuroblastoma lung metastasis. Int. J. Cancer 2013, 133, 2296-2306. [CrossRef] [PubMed]

3. Klein-Goldberg, A.; Maman, S.; Witz, I.P. The role played by the microenvironment in site-specific metastasis. Cancer Lett. 2014, 352, 54-58. [CrossRef] [PubMed]

4. Zhang, C.; Yu, D. Microenvironment determinants of brain metastasis. Cell Biosci. 2011, 1, 8. [CrossRef] 
5. Colombino, M.; Capone, M.; Lissia, A.; Cossu, A.; Rubino, C.; de Giorgi, V.; Massi, D.; Fonsatti, E.; Staibano, S.; Nappi, O.; et al. BRAF/NRAS mutation frequencies among primary tumors and metastases in patients with melanoma. J. Clin. Oncol. 2012, 30, 2522-2529. [CrossRef] [PubMed]

6. Riker, A.I.; Enkemann, S.A.; Fodstad, O.; Liu, S.; Ren, S.; Morris, C.; Xi, Y.; Howell, P.; Metge, B.; Samant, R.S.; et al. The gene expression profiles of primary and metastatic melanoma yields a transition point of tumor progression and metastasis. BMC Med. Genom. 2008, 1, 13. [CrossRef] [PubMed]

7. Brastianos, P.K.; Carter, S.L.; Santagata, S.; Cahill, D.P.; Taylor-Weiner, A.; Jones, R.T.; van Allen, E.M.; Lawrence, M.S.; Horowitz, P.M.; Cibulskis, K.; et al. Genomic characterization of brain metastases reveals branched evolution and potential therapeutic targets. Cancer Discov. 2015, 5, 1164-1177. [CrossRef]

8. Gavrilovic, I.T.; Posner, J.B. Brain metastases: Epidemiology and pathophysiology. J. Neuro-Oncol. 2005, 75, 5-14. [CrossRef] [PubMed]

9. Kienast, Y.; von Baumgarten, L.; Fuhrmann, M.; Klinkert, W.E.F.; Goldbrunner, R.; Herms, J.; Winkler, F. Real-time imaging reveals the single steps of brain metastasis formation. Nat. Med. 2010, 16, 116-122. [CrossRef] [PubMed]

10. Chambers, A.F.; Groom, A.C.; MacDonald, I.C. Dissemination and growth of cancer cells in metastatic sites. Nat. Rev. Cancer 2002, 2, 563-572. [CrossRef] [PubMed]

11. Repesh, L.A.; Fitzgerald, T.J. Interactions of tumor cells with intact capillaries: A model for intravasation. Clin. Exp. Metastasis 1984, 2, 139-150. [CrossRef]

12. Winkelhake, J.L.; Nicolson, G.L. Determination of adhesive properties of variant metastatic melanoma cells to BALB/3T3 cells and their virus-transformed derivatives by a monolayer attachment assay. J. Natl. Cancer Inst. 1976, 56, 285-291. [PubMed]

13. Molnar, J.; Fazakas, C.; Hasko, J.; Sipos, O.; Nagy, K.; Nyul-Toth, A.; Farkas, A.E.; Vegh, A.G.; Varo, G.; Galajda, P.; et al. Transmigration characteristics of breast cancer and melanoma cells through the brain endothelium: Role of Rac and PI3K. Cell Adhes. Migr. 2016, 10, 269-281. [CrossRef] [PubMed]

14. Wilhelm, I.; Molnar, J.; Fazakas, C.; Hasko, J.; Krizbai, I.A. Role of the blood-brain barrier in the formation of brain metastases. Int. J. Mol. Sci. 2013, 14, 1383-1411. [CrossRef] [PubMed]

15. Monteagudo, C.; Pellin-Carcelen, A.; Martin, J.M.; Ramos, D. Role of chemokines in melanoma progression. Actas Dermo-Sifiliogr. 2011, 102, 498-504. [CrossRef] [PubMed]

16. Paget, S. The distribution of secondary growths in cancer of the breast. Lancet 1889, 133, 571-573. [CrossRef]

17. Murakami, T.; Cardones, A.R.; Hwang, S.T. Chemokine receptors and melanoma metastasis. J. Dermatol. Sci. 2004, 36, 71-78. [CrossRef] [PubMed]

18. Borrull, A.; Allard, B.; Wijkhuisen, A.; Herbet, A.; Lamourette, P.; Birouk, W.; Leiber, D.; Tanfin, Z.; Ducancel, F.; Boquet, D.; et al. Rendomab B4, a monoclonal antibody that discriminates the human endothelin $B$ receptor of melanoma cells and inhibits their migration. $m A$ s 2016 . [CrossRef] [PubMed]

19. Izraely, S.; Klein, A.; Sagi-Assif, O.; Meshel, T.; Tsarfaty, G.; Hoon, D.S.B.; Witz, I.P. Chemokine-chemokine receptor axes in melanoma brain metastasis. Immunol. Lett. 2010, 130, 107-114. [CrossRef] [PubMed]

20. Ou, B.; Zhao, J.; Guan, S.; Feng, H.; Wangpu, X.; Zhu, C.; Zong, Y.; Ma, J.; Sun, J.; Shen, X.; et al. CCR4 promotes metastasis via ERK/NF-kappaB/MMP13 pathway and acts downstream of TNF- $\alpha$ in colorectal cancer. Oncotarget 2016, 7, 47637-47649.

21. Yang, Y.; Du, L.; Yang, X.; Qu, A.; Zhang, X.; Zhou, C.; Wang, C. Aberrant CCR4 expression is involved in tumor invasion of lymph node-negative human gastric cancer. PLoS ONE 2015, 10, e0120059. [CrossRef] [PubMed]

22. Li, J.Y.; Ou, Z.L.; Yu, S.J.; Gu, X.L.; Yang, C.; Chen, A.X.; Di, G.H.; Shen, Z.Z.; Shao, Z.M. The chemokine receptor CCR4 promotes tumor growth and lung metastasis in breast cancer. Breast Cancer Res. Treat. 2012, 131, 837-848. [CrossRef] [PubMed]

23. Klein, A.; Sagi-Assif, O.; Izraely, S.; Meshel, T.; Pasmanik-Chor, M.; Nahmias, C.; Couraud, P.-O.; Erez, N.; Hoon, D.S.B.; Witz, I.P. The metastatic microenvironment: Brain-derived soluble factors alter the malignant phenotype of cutaneous and brain-metastasizing melanoma cells. Int. J. Cancer 2012, 131, 2509-2518. [CrossRef] [PubMed]

24. Lok, E.; Chung, A.S.; Swanson, K.D.; Wong, E.T. Melanoma brain metastasis globally reconfigures chemokine and cytokine profiles in patient cerebrospinal fluid. Melanoma Res. 2014, 24, 120-130. [CrossRef] [PubMed]

25. Saldana-Caboverde, A.; Kos, L. Roles of endothelin signaling in melanocyte development and melanoma. Pigment Cell Melanoma Res. 2010, 23, 160-170. [CrossRef] 
26. Cruz-Munoz, W.; Jaramillo, M.L.; Man, S.; Xu, P.; Banville, M.; Collins, C.; Nantel, A.; Francia, G.; Morgan, S.S.; Cranmer, L.D.; et al. Roles for endothelin receptor B and BCL2A1 in spontaneous CNS metastasis of melanoma. Cancer Res. 2012, 72, 4909-4919. [CrossRef] [PubMed]

27. Firth, J.D.; Ratcliffe, P.J. Organ distribution of the three rat endothelin messenger RNAs and the effects of ischemia on renal gene expression. J. Clin. Investig. 1992, 90, 1023-1031. [CrossRef] [PubMed]

28. Wouters, J.; Hunger, R.E.; Garrod, T.; Dubuis, B.; Hunziker, T.; van den Oord, J.J.; Lahav-le Coutre, R. First-in-human proof-of-concept study: Intralesional administration of BQ788, an endothelin receptor B antagonist, to melanoma skin metastases. Oncologist 2015, 20, 1121-1122. [CrossRef] [PubMed]

29. Fabricant, R.N.; de Larco, J.E.; Todaro, G.J. Nerve growth factor receptors on human melanoma cells in culture. Proc. Natl. Acad. Sci. USA 1977, 74, 565-569. [CrossRef] [PubMed]

30. Herlyn, M.; Thurin, J.; Balaban, G.; Bennicelli, J.L.; Herlyn, D.; Elder, D.E.; Bondi, E.; Guerry, D.; Nowell, P.; Clark, W.H.; et al. Characteristics of Cultured Human Melanocytes Isolated from Different Stages of Tumor Progression. Cancer Res. 1985, 45, 5670-5676.

31. Herrmann, J.L.; Menter, D.G.; Hamada, J.; Marchetti, D.; Nakajima, M.; Nicolson, G.L. Mediation of NGF-stimulated extracellular matrix invasion by the human melanoma low-affinity p75 neurotrophin receptor: Melanoma p75 functions independently of trkA. Mol. Biol. Cell 1993, 4, 1205-1216. [CrossRef] [PubMed]

32. Marchetti, D.; Murry, B.; Galjour, J.; Wilke-Greiter, A. Human melanoma TrkC: Its association with a purine-analog-sensitive kinase activity. J. Cell. Biochem. 2003, 88, 865-872. [CrossRef] [PubMed]

33. Marchetti, D.; McCutcheon, I.; Ross, M.; Nicolson, G. Inverse expression of neurotrophins and neurotrophin receptros at the invasion front of human-melanoma brain metastases. Int. J. Oncol. 1995, 7, 87-94. [PubMed]

34. Yoshida, K.; Gage, F.H. Cooperative regulation of nerve growth factor synthesis and secretion in fibroblasts and astrocytes by fibroblast growth factor and other cytokines. Brain Res. 1992, 569, 14-25. [CrossRef]

35. Komai, T.; Okamura, T.; Yamamoto, K.; Fujio, K. The effects of TGF- $\beta$ on immune responses. Jpn J. Clin. Immunol. 2016, 39, 51-58. [CrossRef] [PubMed]

36. Zhang, C.; Zhang, F.; Tsan, R.; Fidler, I.J. Transforming growth factor- $\beta 2$ is a molecular determinant for site-specific melanoma metastasis in the brain. Cancer Res. 2009, 69, 828-835. [CrossRef] [PubMed]

37. Li, J.R.; Wang, J.Q.; Gong, Q.; Fang, R.H.; Guo, Y.L. MicroRNA-328 inhibits proliferation of human melanoma cells by targeting TGF $\beta 2$. Asian Pac. J. Cancer Prev. 2015, 16, 1575-1579. [CrossRef] [PubMed]

38. Abbott, N.J.; Patabendige, A.A.K.; Dolman, D.E.M.; Yusof, S.R.; Begley, D.J. Structure and function of the blood-brain barrier. Neurobiol. Dis. 2010, 37, 13-25. [CrossRef] [PubMed]

39. Brightman, M.W.; Reese, T.S. Junctions between intimately apposed cell membranes in the vertebrate brain. J. Cell Biol. 1969, 40, 648-677. [CrossRef] [PubMed]

40. Vlodavsky, I.; Goldshmidt, O.; Zcharia, E.; Atzmon, R.; Rangini-Guatta, Z.; Elkin, M.; Peretz, T.; Friedmann, Y. Mammalian heparanase: Involvement in cancer metastasis, angiogenesis and normal development. Semin. Cancer Biol. 2002, 12, 121-129. [CrossRef] [PubMed]

41. Marchetti, D. Heparanase: A target for therapy of brain invasive tumors? Exp. Rev. Neurother. 2002, 2, 459-463. [CrossRef] [PubMed]

42. Marchetti, D.; Li, J.; Shen, R. Astrocytes contribute to the metastatic brain specificity of melanoma cells by producing heparanase. Cancer Res. 2000, 60, 4767-4770.

43. Murry, B.P.; Blust, B.E.; Singh, A.; Foster, T.P.; Marchetti, D. Heparanase brain: Mechanisms of melanoma metastasis to the development and use of a brain slice model. J. Cell. Biochem. 2006, 97, 217-225. [CrossRef]

44. Marchetti, D.; Menter, D.; Jin, L.; Nakajima, M.; Nicolson, G.L. Nerve growth factor effects on human and mouse melanoma cell invasion and heparanase production. Int. J. Cancer 1993, 55, 692-699. [CrossRef] [PubMed]

45. Liu, X.; Fang, H.; Chen, H.; Jiang, X.; Fang, D.; Wang, Y.; Zhu, D. An artificial miRNA against HPSE suppresses melanoma invasion properties, correlating with a down-regulation of chemokines and MAPK phosphorylation. PLoS ONE 2012, 7, e38659. [CrossRef] [PubMed]

46. Zhang, L.; Sullivan, P.S.; Goodman, J.C.; Gunaratne, P.H.; Marchetti, D. MicroRNA-1258 suppresses breast cancer brain metastasis by targeting heparanase. Cancer Res. 2011, 71, 645-654. [CrossRef] [PubMed]

47. Fazakas, C.; Wilhelm, I.; Nagyoszi, P.; Farkas, A.E.; Hasko, J.; Molnar, J.; Bauer, H.; Bauer, H.C.; Ayaydin, F.; Dung, N.T.; et al. Transmigration of melanoma cells through the blood-brain barrier: Role of endothelial tight junctions and melanoma-released serine proteases. PLoS ONE 2011, 6, e20758. [CrossRef] [PubMed] 
48. Hsu, M.; Andl, T.; Li, G.; Meinkoth, J.L.; Herlyn, M. Cadherin repertoire determines partner-specific gap junctional communication during melanoma progression. J. Cell Sci. 2000, 113, 1535-1542. [PubMed]

49. Ito, A.; Katoh, F.; Kataoka, T.R.; Okada, M.; Tsubota, N.; Asada, H.; Yoshikawa, K.; Maeda, S.; Kitamura, Y.; Yamasaki, H.; et al. A role for heterologous gap junctions between melanoma and endothelial cells in metastasis. J. Clin. Investig. 2000, 105, 1189-1197. [CrossRef] [PubMed]

50. Stoletov, K.; Strnadel, J.; Zardouzian, E.; Momiyama, M.; Park, F.D.; Kelber, J.A.; Pizzo, D.P.; Hoffman, R.; VandenBerg, S.R.; Klemke, R.L. Role of connexins in metastatic breast cancer and melanoma brain colonization. J. Cell Sci. 2013, 126, 904-913. [CrossRef] [PubMed]

51. Sargen, M.R.; Gormley, R.H.; Pasha, T.L.; Yum, S.; Acs, G.; Xu, X.; Zhang, P.J. Melanocytic tumors express connexin 43 but not 26: Immunohistochemical analysis with potential significance in melanocytic oncogenesis. Am. J. Dermatopathol. 2013, 35, 813-817. [CrossRef]

52. Ableser, M.J.; Penuela, S.; Lee, J.; Shao, Q.; Laird, D.W. Connexin43 reduces melanoma growth within a keratinocyte microenvironment and during tumorigenesis in vivo. J. Biol. Chem. 2014, 289, 1592-1603. [CrossRef] [PubMed]

53. Tittarelli, A.; Guerrero, I.; Tempio, F.; Gleisner, M.A.; Avalos, I.; Sabanegh, S.; Ortiz, C.; Michea, L.; Lopez, M.N.; Mendoza-Naranjo, A.; et al. Overexpression of connexin 43 reduces melanoma proliferative and metastatic capacity. Br. J. Cancer 2015, 113, 259-267. [CrossRef] [PubMed]

54. Herwig, N.; Belter, B.; Pietzsch, J. Extracellular S100A4 affects endothelial cell integrity and stimulates transmigration of A375 melanoma cells. Biochem. Biophys. Res. Commun. 2016, 477, 963-969. [CrossRef] [PubMed]

55. Herwig, N.; Belter, B.; Wolf, S.; Haase-Kohn, C.; Pietzsch, J. Interaction of extracellular S100A4 with RAGE prompts prometastatic activation of A375 melanoma cells. J. Cell. Mol. Med. 2016, 20, 825-835. [CrossRef] [PubMed]

56. Medapati, M.R.; Dahlmann, M.; Ghavami, S.; Pathak, K.A.; Lucman, L.; Klonisch, T.; Hoang-Vu, C.; Stein, U.; Hombach-Klonisch, S. RAGE mediates the pro-migratory response of extracellular S100A4 in human thyroid cancer cells. Thyroid 2015, 25, 514-527. [CrossRef] [PubMed]

57. Dahlmann, M.; Okhrimenko, A.; Marcinkowski, P.; Osterland, M.; Herrmann, P.; Smith, J.; Heizmann, C.W.; Schlag, P.M.; Stein, U. RAGE mediates S100A4-induced cell motility via MAPK/ERK and hypoxia signaling and is a prognostic biomarker for human colorectal cancer metastasis. Oncotarget 2014, 5, 3220-3233. [CrossRef] [PubMed]

58. Siddique, H.R.; Adhami, V.M.; Parray, A.; Johnson, J.J.; Siddiqui, I.A.; Shekhani, M.T.; Murtaza, I.; Ambartsumian, N.; Konety, B.R.; Mukhtar, H.; et al. The S100A4 oncoprotein promotes prostate tumorigenesis in a transgenic mouse model: Regulating NFKB through the rage receptor. Genes Cancer 2013, 4, 224-234. [CrossRef] [PubMed]

59. Hernandez, J.L.; Padilla, L.; Dakhel, S.; Coll, T.; Hervas, R.; Adan, J.; Masa, M.; Mitjans, F.; Martinez, J.M.; Coma, S.; et al. Therapeutic targeting of tumor growth and angiogenesis with a novel anti-S100A4 monoclonal antibody. PLoS ONE 2013, 8, e72480. [CrossRef] [PubMed]

60. Jilaveanu, L.B.; Parisi, F.; Barr, M.L.; Zito, C.R.; Cruz-Munoz, W.; Kerbel, R.S.; Rimm, D.L.; Bosenberg, M.W.; Halaban, R.; Kluger, Y.; et al. PLEKHA5 as a Biomarker and Potential Mediator of Melanoma Brain Metastasis. Clin. Cancer Res. 2015, 21, 2138-2147. [CrossRef] [PubMed]

61. Klein, A.; Schwartz, H.; Sagi-Assif, O.; Meshel, T.; Izraely, S.; Ben Menachem, S.; Bengaiev, R.; Ben-Shmuel, A.; Nahmias, C.; Couraud, P.O.; et al. Astrocytes facilitate melanoma brain metastasis via secretion of IL-23. J. Pathol. 2015, 236, 116-127. [CrossRef] [PubMed]

62. Tang, Q.; Li, J.; Zhu, H.; Li, P.; Zou, Z.; Xiao, Y. Hmgb1-IL-23-IL-17-IL-6-Stat3 axis promotes tumor growth in murine models of melanoma. Med. Inflamm. 2013, 2013, 713859. [CrossRef] [PubMed]

63. Xie, T.X.; Huang, F.J.; Aldape, K.D.; Kang, S.H.; Liu, M.; Gershenwald, J.E.; Xie, K.; Sawaya, R.; Huang, S. Activation of stat3 in human melanoma promotes brain metastasis. Cancer Res. 2006, 66, 3188-3196. [CrossRef] [PubMed]

64. Redondo, P.; Lloret, P.; Idoate, M.; Inoges, S. Expression and serum levels of MMP-2 and MMP-9 during human melanoma progression. Clin. Exp. Dermatol. 2005, 30, 541-545. [CrossRef] [PubMed]

65. Rotte, A.; Martinka, M.; Li, G. MMP2 expression is a prognostic marker for primary melanoma patients. Cell. Oncol. 2012, 35, 207-216. [CrossRef] [PubMed] 
66. Rizzo, A.; Vasco, C.; Girgenti, V.; Fugnanesi, V.; Calatozzolo, C.; Canazza, A.; Salmaggi, A.; Rivoltini, L.; Morbin, M.; Ciusani, E. Melanoma cells homing to the brain: An in vitro model. BioMed Res. Int. 2015, 2015, 476069. [CrossRef] [PubMed]

67. Ishihara, H.; Kubota, H.; Lindberg, R.L.; Leppert, D.; Gloor, S.M.; Errede, M.; Virgintino, D.; Fontana, A.; Yonekawa, Y.; Frei, K. Endothelial cell barrier impairment induced by glioblastomas and transforming growth factor $\beta 2$ involves matrix metalloproteinases and tight junction proteins. J. Neuropathol. Exp. Neurol. 2008, 67, 435-448. [CrossRef] [PubMed]

68. Wolff, A.; Antfolk, M.; Brodin, B.; Tenje, M. In vitro blood-brain barrier models-An overview of established models and new microfluidic approaches. J. Pharm. Sci. 2015, 104, 2727-2746. [CrossRef] [PubMed]

69. Berghoff, A.S.; Rajky, O.; Winkler, F.; Bartsch, R.; Furtner, J.; Hainfellner, J.A.; Goodman, S.L.; Weller, M.; Schittenhelm, J.; Preusser, M. Invasion patterns in brain metastases of solid cancers. Neuro-Oncology 2013, 15, 1664-1672. [CrossRef] [PubMed]

70. Huang, F.J.; Steeg, P.S.; Price, J.E.; Chiu, W.T.; Chou, P.C.; Xie, K.; Sawaya, R.; Huang, S. Molecular basis for the critical role of suppressor of cytokine signaling-1 in melanoma brain metastasis. Cancer Res. 2008, 68, 9634-9642. [CrossRef] [PubMed]

71. Ilhan-Mutlu, A.; Siehs, C.; Berghoff, A.S.; Ricken, G.; Widhalm, G.; Wagner, L.; Preusser, M. Expression profiling of angiogenesis-related genes in brain metastases of lung cancer and melanoma. Tumour Biol. 2016, 37, 1173-1182. [CrossRef] [PubMed]

72. Ju, R.; Zhuang, Z.W.; Zhang, J.; Lanahan, A.A.; Kyriakides, T.; Sessa, W.C.; Simons, M. Angiopoietin-2 Secretion by Endothelial Cell Exosomes: Regulation by the Phosphatidylinositol 3-kinase (PI3K)/Akt/Endothelial nitric oxide synthase (eNOS) and Syndecan-4/Synthenin pathways. J. Biol. Chem. 2014, 289, 510-519. [CrossRef] [PubMed]

73. Karar, J.; Maity, A. PI3K/AKT/mTOR pathway in Angiogenesis. Front. Mol. Neurosci. 2011. [CrossRef] [PubMed]

74. Phung, T.L.; Du, W.; Xue, Q.; Ayyaswamy, S.; Gerald, D.; Antonello, Z.; Nhek, S.; Perruzzi, C.A.; Acevedo, I.; Ramanna-Valmiki, R.; et al. Akt1 and Akt3 exert opposing roles in the regulation of vascular tumor growth. Cancer Res. 2015, 75, 40-50. [CrossRef] [PubMed]

75. Phung, T.L.; Ziv, K.; Dabydeen, D.; Eyiah-Mensah, G.; Riveros, M.; Perruzzi, C.; Sun, J.; Monahan-Earley, R.A.; Shiojima, I.; Nagy, J.A.; et al. Pathological angiogenesis is induced by sustained Akt signaling and inhibited by rapamycin. Cancer Cell 2006, 10, 159-170. [CrossRef] [PubMed]

76. Yuan, T.L.; Cantley, L.C. PI3K pathway alterations in cancer: Variations on a theme. Oncogene 2008, 27, 5497-5510. [CrossRef] [PubMed]

77. Dai, D.L.; Martinka, M.; Li, G. Prognostic significance of activated Akt expression in melanoma: A clinicopathologic study of 292 cases. J. Clin. Oncol. 2005, 23, 1473-1482. [CrossRef] [PubMed]

78. Davies, M.A.; Stemke-Hale, K.; Lin, E.; Tellez, C.; Deng, W.; Gopal, Y.N.; Woodman, S.E.; Calderone, T.C.; Ju, Z.; Lazar, A.J.; et al. Integrated molecular and clinical analysis of Akt activation in metastatic melanoma. Clin. Cancer Res. 2009, 15, 7538-7546. [CrossRef] [PubMed]

79. Smalley, K.S.M. Understanding melanoma signaling networks as the basis for molecular targeted therapy. J. Investig. Dermatol. 2009, 130, 28-37. [CrossRef] [PubMed]

80. Altomare, D.A.; Testa, J.R. Perturbations of the AKT signaling pathway in human cancer. Oncogene 2005, 24, 7455-7464. [CrossRef] [PubMed]

81. Hemmings, B.A.; Restuccia, D.F. PI3K-PKB/Akt pathway. Cold Spring Harb. Perspect. Biol. 2012, 4, a011189. [CrossRef] [PubMed]

82. Manning, B.D.; Cantley, L.C. AKT/PKB signaling: Navigating downstream. Cell 2007, 129, 1261-1274. [CrossRef] [PubMed]

83. Davies, M.A.; Stemke-Hale, K.; Tellez, C.; Calderone, T.L.; Deng, W.; Prieto, V.G.; Lazar, A.J.F.; Gershenwald, J.E.; Mills, G.B. A novel AKT3 mutation in melanoma tumours and cell lines. Br. J. Cancer 2008, 99, 1265-1268. [CrossRef] [PubMed]

84. Manca, A.; Lissia, A.; Capone, M.; Ascierto, P.A.; Botti, G.; Caraco, C.; Stanganelli, I.; Colombino, M.; Sini, M.; Cossu, A.; et al. Activating PIK3CA mutations coexist with BRAF or NRAS mutations in a limited fraction of melanomas. J. Transl. Med. 2015, 13, 37. [CrossRef] [PubMed]

85. The Cancer Genome Atlas Network. Genomic classification of cutaneous melanoma. Cell 2015, 161, 1681-1696. 
86. Bunney, T.D.; Katan, M. Phosphoinositide signalling in cancer: Beyond PI3K and PTEN. Nat. Rev. Cancer 2010, 10, 342-352. [CrossRef] [PubMed]

87. Glitza, I.C.; Davies, M.A. Genotyping of cutaneous melanoma. Chin. Clin. Oncol. 2014, 3, 27. [PubMed]

88. Davies, M.A. The role of the PI3K-AKT pathway in melanoma. Cancer J. 2012, 18, 142-147. [CrossRef] [PubMed]

89. Whiteman, D.C.; Zhou, X.P.; Cummings, M.C.; Pavey, S.; Hayward, N.K.; Eng, C. Nuclear PTEN expression and clinicopathologic features in a population-based series of primary cutaneous melanoma. Int. J. Cancer 2002, 99, 63-67. [CrossRef] [PubMed]

90. Poetsch, M.; Dittberner, T.; Woenckhaus, C. PTEN/MMAC1 in malignant melanoma and its importance for tumor progression. Cancer Genet. Cytogenet. 2001, 125, 21-26. [CrossRef]

91. Stahl, J.M.; Sharma, A.; Cheung, M.; Zimmerman, M.; Cheng, J.Q.; Bosenberg, M.W.; Kester, M.; Sandirasegarane, L.; Robertson, G.P. Deregulated Akt3 activity promotes development of malignant melanoma. Cancer Res. 2004, 64, 7002-7010. [CrossRef] [PubMed]

92. Govindarajan, B.; Sligh, J.E.; Vincent, B.J.; Li, M.; Canter, J.A.; Nickoloff, B.J.; Rodenburg, R.J.; Smeitink, J.A.; Oberley, L.; Zhang, Y.; et al. Overexpression of Akt converts radial growth melanoma to vertical growth melanoma. J. Clin. Investig. 2007, 117, 719-729. [CrossRef] [PubMed]

93. Bucheit, A.D.; Chen, G.; Siroy, A.; Tetzlaff, M.; Broaddus, R.; Milton, D.; Fox, P.; Bassett, R.; Hwu, P.; Gershenwald, J.E.; et al. Complete loss of PTEN protein expression correlates with shorter time to brain metastasis and survival in stage IIIB/C melanoma patients with $\mathrm{BRAF}^{\mathrm{V} 600}$ mutations. Clin. Cancer Res. 2014, 20, 5527-5536. [CrossRef] [PubMed]

94. Niessner, H.; Forschner, A.; Klumpp, B.; Honegger, J.B.; Witte, M.; Bornemann, A.; Dummer, R.; Adam, A.; Bauer, J.; Tabatabai, G.; et al. Targeting hyperactivation of the AKT survival pathway to overcome therapy resistance of melanoma brain metastases. Cancer Med. 2013, 2, 76-85. [CrossRef] [PubMed]

95. Chen, G.; Chakravarti, N.; Aardalen, K.; Lazar, A.J.; Tetzlaff, M.T.; Wubbenhorst, B.; Kim, S.-B.; Kopetz, S.; Ledoux, A.A.; Gopal, Y.N.V.; et al. Molecular profiling of patient-matched brain and extracranial melanoma metastases implicates the PI3K pathway as a therapeutic target. Clin. Cancer Res. 2014, 20, 5537-5546. [CrossRef] [PubMed]

96. Cho, J.H.; Robinson, J.P.; Arave, R.A.; Burnett, W.J.; Kircher, D.A.; Chen, G.; Davies, M.A.; Grossmann, A.H.; VanBrocklin, M.W.; McMahon, M.; et al. AKT1 Activation promotes development of melanoma metastases. Cell Rep. 2015, 13, 898-905. [CrossRef] [PubMed]

97. Zetser, A.; Bashenko, Y.; Edovitsky, E.; Levy-Adam, F.; Vlodavsky, I.; Ilan, N. Heparanase induces vascular endothelial growth factor expression: Correlation with p38 phosphorylation levels and Src activation. Cancer Res. 2006, 66, 1455-1463. [CrossRef] [PubMed]

98. Park, D.J.; Wallick, C.J.; Martyn, K.D.; Lau, A.F.; Jin, C.; Warn-Cramer, B.J. Akt phosphorylates Connexin43 on Ser373, a "mode-1" binding site for 14-3-3. Cell Commun. Adhes. 2007, 14, 211-226. [CrossRef] [PubMed]

99. Vogt, P.K.; Hart, J.R. PI3K and STAT3: A new alliance. Cancer Discov. 2011, 1, 481-486. [CrossRef] [PubMed]

100. Park, E.S.; Kim, S.J.; Kim, S.W.; Yoon, S.L.; Leem, S.H.; Kim, S.B.; Kim, S.M.; Park, Y.Y.; Cheong, J.H.; Woo, H.G.; et al. Cross-species hybridization of microarrays for studying tumor transcriptome of brain metastasis. Proc. Natl. Acad. Sci. USA 2011, 108, 17456-17461. [CrossRef] [PubMed]

101. Liu, S.Q.; Jiang, S.; Li, C.; Zhang, B.; Li, Q.J. miR-17-92 cluster targets phosphatase and tensin homology and Ikaros Family Zinc Finger 4 to promote TH17-mediated inflammation. J. Biol. Chem. 2014, 289, 12446-12456. [CrossRef] [PubMed]

102. Olive, V.; Bennett, M.J.; Walker, J.C.; Ma, C.; Jiang, I.; Cordon-Cardo, C.; Li, Q.J.; Lowe, S.W.; Hannon, G.J.; He, L. miR-19 is a key oncogenic component of mir-17-92. Genes Dev. 2009, 23, 2839-2849. [CrossRef] [PubMed]

103. Olive, V.; Jiang, I.; He, L. mir-17-92, a cluster of miRNAs in the midst of the cancer network. Int. J. Biochem. Cell Biol. 2010, 42, 1348-1354. [CrossRef] [PubMed]

104. Zhu, H.; Han, C.; Lu, D.; Wu, T. miR-17-92 cluster promotes cholangiocarcinoma growth: Evidence for PTEN as downstream target and IL-6/Stat3 as upstream activator. Am. J. Pathol. 2014, 184, 2828-2839. [CrossRef] [PubMed]

105. Zhang, L.; Zhang, S.; Yao, J.; Lowery, F.J.; Zhang, Q.; Huang, W.C.; Li, P.; Li, M.; Wang, X.; Zhang, C.; et al. Microenvironment-induced PTEN loss by exosomal microRNA primes brain metastasis outgrowth. Nature 2015, 527, 100-104. [CrossRef] [PubMed] 
106. Cruz-Munoz, W.; Man, S.; Xu, P.; Kerbel, R.S. Development of a Preclinical Model of Spontaneous Human Melanoma Central Nervous System Metastasis. Cancer Res. 2008, 68, 4500-4505. [CrossRef] [PubMed]

107. Niessner, H.; Schmitz, J.; Tabatabai, G.; Schmid, A.; Calaminus, C.; Sinnberg, T.; Weide, B.; Eigentler, T.K.; Garbe, C.; Schittek, B.; et al. PI3K pathway inhibition achieves potent antitumor activity in melanoma brain metastases in vitro and in vivo. Clin. Cancer Res. 2016. [CrossRef] [PubMed]

108. Sundstrom, T.; Daphu, I.; Wendelbo, I.; Hodneland, E.; Lundervold, A.; Immervoll, H.; Skaftnesmo, K.O.; Babic, M.; Jendelova, P.; Sykova, E.; et al. Automated tracking of nanoparticle-labeled melanoma cells improves the predictive power of a brain metastasis model. Cancer Res. 2013, 73, 2445-2456. [CrossRef]

109. Izraely, S.; Sagi-Assif, O.; Klein, A.; Meshel, T.; Tsarfaty, G.; Pasmanik-Chor, M.; Nahmias, C.; Couraud, P.O.; Ateh, E.; Bryant, J.L.; et al. The metastatic microenvironment: Brain-residing melanoma metastasis and dormant micrometastasis. Int. J. Cancer 2012, 131, 1071-1082. [CrossRef] [PubMed]

110. Yano, S.; Shinohara, H.; Herbst, R.S.; Kuniyasu, H.; Bucana, C.D.; Ellis, L.M.; Davis, D.W.; McConkey, D.J.; Fidler, I.J. Expression of vascular endothelial growth factor is necessary but not sufficient for production and growth of brain metastasis. Cancer Res. 2000, 60, 4959-4967.

111. Fujimaki, T.; Price, J.E.; Fan, D.; Bucana, C.D.; Itoh, K.; Kirino, T.; Fidler, I.J. Selective growth of human melanoma cells in the brain parenchyma of nude mice. Melanoma Res. 1996, 6, 363-371. [CrossRef] [PubMed]

112. Kato, M.; Takahashi, M.; Akhand, A.A.; Liu, W.; Dai, Y.; Shimizu, S.; Iwamoto, T.; Suzuki, H.; Nakashima, I. Transgenic mouse model for skin malignant melanoma. Oncogene 1998, 17, 1885-1888. [CrossRef] [PubMed]

113. Umansky, V.; Abschuetz, O.; Osen, W.; Ramacher, M.; Zhao, F.; Kato, M.; Schadendorf, D. Melanoma-specific memory $\mathrm{T}$ cells are functionally active in Ret transgenic mice without macroscopic tumors. Cancer Res. 2008, 68, 9451-9458. [CrossRef] [PubMed]

114. Schwartz, H.; Blacher, E.; Amer, M.; Livneh, N.; Abramovitz, L.; Klein, A.; Ben-Shushan, D.; Soffer, S.; Blazquez, R.; Barrantes-Freer, A.; et al. Incipient melanoma brain metastases instigate astrogliosis and neuroinflammation. Cancer Res. 2016, 76, 4359-4371. [CrossRef] [PubMed]

115. Morsi, A.; Gaziel-Sovran, A.; Cruz-Munoz, W.; Kerbel, R.S.; Golfinos, J.G.; Hernando, E.; Wadghiri, Y.Z. Development and characterization of a clinically relevant mouse model of melanoma brain metastasis. Pigment Cell Melanoma Res. 2013, 26, 743-745. [CrossRef] [PubMed]

116. Heilmann, S.; Ratnakumar, K.; Langdon, E.M.; Kansler, E.R.; Kim, I.S.; Campbell, N.R.; Perry, E.B.; McMahon, A.J.; Kaufman, C.K.; van Rooijen, E.; et al. A Quantitative system for studying metastasis using transparent zebrafish. Cancer Res. 2015, 75, 4272-4282. [CrossRef] [PubMed]

117. Budman, D.R.; Camacho, E.; Wittes, R.E. The current causes of death in patients with malignant melanoma. Eur. J. Cancer 1978, 14, 327-330. [CrossRef]

118. Davies, M.A.; Liu, P.; McIntyre, S.; Kim, K.B.; Papadopoulos, N.; Hwu, W.-J.; Hwu, P.; Bedikian, A. Prognostic factors for survival in melanoma patients with brain metastases. Cancer 2011, 117, 1687-1696. [CrossRef] [PubMed]

119. Sandru, A.; Voinea, S.; Panaitescu, E.; Blidaru, A. Survival rates of patients with metastatic malignant melanoma. J. Med. Life 2014, 7, 572-576. [PubMed]

120. Sampson, J.H.; Carter, J.H., Jr.; Friedman, A.H.; Seigler, H.F. Demographics, prognosis, and therapy in 702 patients with brain metastases from malignant melanoma. J. Neurosurg. 1998, 88, 11-20. [CrossRef] [PubMed]

121. Marchetti, D.; Denkins, Y.; Reiland, J.; Greiter-Wilke, A.; Galjour, J.; Murry, B.; Blust, J.; Roy, M. Brain-metastatic melanoma: A neurotrophic perspective. Pathol. Oncol. Res. 2003, 9, 147-158. [CrossRef] [PubMed]

122. Steeg, P.S.; Camphausen, K.A.; Smith, Q.R. Brain metastases as preventive and therapeutic targets. Nat. Rev. Cancer 2011, 11, 352-363. [CrossRef] [PubMed]

123. Amer, M.H.; Al-Sarraf, M.; Baker, L.H.; Vaitkevicius, V.K. Malignant melanoma and central nervous system metastases. Incidence, diagnosis, treatment and survival. Cancer 1978, 42, 660-668. [CrossRef]

124. Chaichana, K.K.; Chaichana, K.L. Diagnosis and Treatment Options for Brain Metastasis of Melanoma; INTECH Open Access Publisher: Vienna, Austria, 2011.

125. Tas, F. Metastatic behavior in melanoma: Timing, pattern, survival, and influencing factors. J. Oncol. 2012, 2012. [CrossRef] [PubMed] 
126. Fife, K.M.; Colman, M.H.; Stevens, G.N.; Firth, I.C.; Moon, D.; Shannon, K.F.; Harman, R.; Petersen-Schaefer, K.; Zacest, A.C.; Besser, M.; et al. Determinants of outcome in melanoma patients with cerebral metastases. J. Clin. Oncol. 2004, 22, 1293-1300. [CrossRef] [PubMed]

127. Vecchio, S.; Spagnolo, F.; Merlo, D.F.; Signori, A.; Acquati, M.; Pronzato, P.; Queirolo, P. The treatment of melanoma brain metastases before the advent of targeted therapies: Associations between therapeutic choice, clinical symptoms and outcome with survival. Melanoma Res. 2014, 24, 61-67. [CrossRef] [PubMed]

128. Sperduto, P.W.; Berkey, B.; Gaspar, L.E.; Mehta, M.; Curran, W. A new prognostic index and comparison to three other indices for patients with brain metastases: An analysis of 1,960 patients in the RTOG database. Int. J. Radiat. Oncol. Biol. Phys. 2008, 70, 510-514. [CrossRef] [PubMed]

129. Sperduto, P.W.; Kased, N.; Roberge, D.; Xu, Z.; Shanley, R.; Luo, X.; Sneed, P.K.; Chao, S.T.; Weil, R.J.; Suh, J.; et al. Summary report on the graded prognostic assessment: An accurate and facile diagnosis-specific tool to estimate survival for patients with brain metastases. J. Clin. Oncol. 2012, 30, 419-425. [CrossRef] [PubMed]

130. Wilkins, A.; Furness, A.; Corbett, R.W.; Bloomfield, A.; Porta, N.; Morris, S.; Ali, Z.; Larkin, J.; Harrington, K. The melanoma-specific graded prognostic assessment does not adequately discriminate prognosis in a modern population with brain metastases from malignant melanoma. Br. J. Cancer 2015, 113, 1275-1281. [CrossRef] [PubMed]

131. Ewend, M.G.; Carey, L.A.; Brem, H. Treatment of melanoma metastases in the brain. Semin. Surg. Oncol. 1996, 12, 429-435. [CrossRef]

132. Marek, W.; Ehud, A. Surgical treatment of brain metastases from melanoma: A retrospective study of 91 patients. J. Neurosurg. 2000, 93, 9-18.

133. Gorantla, V.; Kirkwood, J.; Tawbi, H. Melanoma brain metastases: An unmet challenge in the era of active therapy. Curr. Oncol. Rep. 2013, 15, 483-491. [CrossRef] [PubMed]

134. Eichler, A.F.; Loeffler, J.S. Multidisciplinary management of brain metastases. Oncologist 2007, 12, 884-898. [CrossRef]

135. Flanigan, J.C.; Jilaveanu, L.B.; Faries, M.; Sznol, M.; Ariyan, S.; Yu, J.B.; Knisely, J.P.S.; Chiang, V.L.; Kluger, H.M. Melanoma Brain Metastases: Is It Time to Reassess the Bias? Curr. Probl. Cancer 2011, 35, 200-210. [CrossRef] [PubMed]

136. Chukwueke, U.; Batchelor, T.; Brastianos, P. Management of brain metastases in patients with melanoma. J. Oncol. Pract. 2016, 12, 536-542. [CrossRef] [PubMed]

137. Spagnolo, F.; Picasso, V.; Lambertini, M.; Ottaviano, V.; Dozin, B.; Queirolo, P. Survival of patients with metastatic melanoma and brain metastases in the era of MAP-kinase inhibitors and immunologic checkpoint blockade antibodies: A systematic review. Cancer Treat. Rev. 2016, 45, 38-45. [CrossRef] [PubMed]

138. Goulart, C.R.; Mattei, T.A.; Ramina, R. Cerebral melanoma metastases: A critical review on diagnostic methods and therapeutic options. ISRN Surg. 2011. [CrossRef] [PubMed]

139. Sperduto, P.W.; Chao, S.T.; Sneed, P.K.; Luo, X.; Suh, J.; Roberge, D.; Bhatt, A.; Jensen, A.W.; Brown, P.D.; Shih, H.; et al. Diagnosis-specific prognostic factors, indexes, and treatment outcomes for patients with newly diagnosed brain metastases: A multi-institutional analysis of 4259 patients. Int. J. Radiat. Oncol. Biol. Phys. 2010, 77, 655-661. [CrossRef] [PubMed]

140. Khan, A.J.; Dicker, A.P. On the Merits and limitations of whole-brain radiation therapy. J. Clin. Oncol. 2013, 31, 11-13. [CrossRef] [PubMed]

141. Hatiboglu, M.A.; Wildrick, D.M.; Sawaya, R. The role of surgical resection in patients with brain metastases. Ecancermedicalscience 2013, 7, 308. [PubMed]

142. Barranco, S.C.; Romsdahl, M.M.; Humphrey, R.M. The Radiation response of human malignant melanoma cells grown in vitro. Cancer Res. 1971, 31, 830-833. [PubMed]

143. Goldinger, S.M.; Panje, C.; Nathan, P. Treatment of melanoma brain metastases. Curr. Opin. Oncol. 2016, 28, 159-165. [CrossRef] [PubMed]

144. Tsao, M.N.; Rades, D.; Wirth, A.; Lo, S.S.; Danielson, B.L.; Gaspar, L.E.; Sperduto, P.W.; Vogelbaum, M.A.; Radawski, J.D.; Wang, J.Z.; et al. Radiotherapeutic and surgical management for newly diagnosed brain metastasis(es): An American Society for Radiation Oncology evidence-based guideline. Pract. Radiat. Oncol. 2012, 2, 210-225. [CrossRef] [PubMed]

145. Staudt, M.; Lasithiotakis, K.; Leiter, U.; Meier, F.; Eigentler, T.; Bamberg, M.; Tatagiba, M.; Brossart, P.; Garbe, C. Determinants of survival in patients with brain metastases from cutaneous melanoma. Br. J. Cancer 2010, 102, 1213-1218. [CrossRef] [PubMed] 
146. Skibber, J.M.; Soong, S.J.; Austin, L.; Balch, C.M.; Sawaya, R.E. Cranial irradiation after surgical excision of brain metastases in melanoma patients. Ann. Surg. Oncol. 1996, 3, 118-123. [CrossRef] [PubMed]

147. Hagen, N.A.; Cirrincione, C.; Thaler, H.T.; DeAngelis, L.M. The role of radiation therapy following resection of single brain metastasis from melanoma. Neurology 1990, 40, 158-160. [CrossRef] [PubMed]

148. Nieder, C.; Grosu, A.; Gaspar, L. Stereotactic radiosurgery (SRS) for brain metastases: A systematic review. Radiat. Oncol. 2014, 9, 155. [CrossRef] [PubMed]

149. Aoyama, H.; Shirato, H.; Tago, M.; Nakagawa, K.; Toyoda, T.; Hatano, K.; Kenjyo, M.; Oya, N.; Hirota, S.; Shioura, H.; et al. Stereotactic radiosurgery plus whole-brain radiation therapy vs stereotactic radiosurgery alone for treatment of brain metastases: A randomized controlled trial. JAMA 2006, 295, 2483-2491. [CrossRef] [PubMed]

150. Sahgal, A.; Aoyama, H.; Kocher, M.; Neupane, B.; Collette, S.; Tago, M.; Shaw, P.; Beyene, J.; Chang, E.L. Phase 3 trials of stereotactic radiosurgery with or without whole-brain radiation therapy for 1 to 4 brain metastases: Individual patient data meta-analysis. Int. J. Radiat. Oncol. Biol. Phys. 2015, 91, 710-717. [CrossRef] [PubMed]

151. Chowdhury, I.H.; Ojerholm, E.; McMillan, M.T.; Miller, D.; Kolker, J.D.; Kurtz, G.; Dorsey, J.F.; Nagda, S.N.; Geiger, G.A.; Brem, S.; et al. Novel risk scores for survival and intracranial failure in patients treated with radiosurgery alone to melanoma brain metastases. Radiat. Oncol. 2015, 10, 248. [CrossRef] [PubMed]

152. DeAngelis, L.M.; Delattre, J.Y.; Posner, J.B. Radiation-induced dementia in patients cured of brain metastases. Neurology 1989, 39, 789-796. [CrossRef] [PubMed]

153. Goyal, S.; Silk, A.W.; Tian, S.; Mehnert, J.; Danish, S.; Ranjan, S.; Kaufman, H.L. Clinical management of multiple melanoma brain metastases: A systematic review. JAMA Oncol. 2015, 1, 668-676. [CrossRef] [PubMed]

154. Agarwala, S.S.; Kirkwood, J.M.; Gore, M.; Dreno, B.; Thatcher, N.; Czarnetski, B.; Atkins, M.; Buzaid, A.; Skarlos, D.; Rankin, E.M. Temozolomide for the treatment of brain metastases associated with metastatic melanoma: A phase II study. J. Clin. Oncol. 2004, 22, 2101-2107. [CrossRef] [PubMed]

155. Avril, M.F.; Aamdal, S.; Grob, J.J.; Hauschild, A.; Mohr, P.; Bonerandi, J.J.; Weichenthal, M.; Neuber, K.; Bieber, T.; Gilde, K.; et al. Fotemustine compared with dacarbazine in patients with disseminated malignant melanoma: A phase III study. J. Clin. Oncol. 2004, 22, 1118-1125. [CrossRef] [PubMed]

156. Schadendorf, D.; Fisher, D.E.; Garbe, C.; Gershenwald, J.E.; Grob, J.J.; Halpern, A.; Herlyn, M.; Marchetti, M.A.; McArthur, G.; Ribas, A.; et al. Melanoma. Nat. Rev. Dis. Primers 2015, 1, 15003. [CrossRef] [PubMed]

157. Long, G.V.; Trefzer, U.; Davies, M.A.; Kefford, R.F.; Ascierto, P.A.; Chapman, P.B.; Puzanov, I.; Hauschild, A.; Robert, C.; Algazi, A.; et al. Dabrafenib in patients with Val600Glu or Val600Lys BRAF-mutant melanoma metastatic to the brain (BREAK-MB): A multicentre, open-label, phase 2 trial. Lancet Oncol. 2012, 13, 1087-1095. [CrossRef]

158. Kefford, R.F.; Maio, M.; Arance, A.; Nathan, P.; Blank, C.; Avril, M.F. Vemurafenib in metastatic melanoma patients with brain metastases: An open-label, singlearm, phase 2, multicenter study. Pigment Cell Melanoma Res. 2013, 26, 965.

159. Maxwell, R.; Garzon-Muvdi, T.; Lipson, E.J.; Sharfman, W.H.; Bettegowda, C.; Redmond, K.J.; Kleinberg, L.R.; Ye, X.; Lim, M. BRAF-V600 mutational status affects recurrence patterns of melanoma brain metastasis. Int. J. Cancer 2016. [CrossRef] [PubMed]

160. Gummadi, T.; Zhang, B.Y.; Valpione, S.; Kim, C.; Kottschade, L.A.; Mittapalli, R.K.; Chiarion-Sileni, V.; Pigozzo, J.; Elmquist, W.F.; Dudek, A.Z. Impact of BRAF mutation and BRAF inhibition on melanoma brain metastases. Melanoma Res. 2015, 25, 75-79. [CrossRef] [PubMed]

161. Chapman, P.B.; Hauschild, A.; Robert, C.; Haanen, J.B.; Ascierto, P.; Larkin, J.; Dummer, R.; Garbe, C.; Testori, A.; Maio, M.; et al. Improved survival with vemurafenib in melanoma with BRAF ${ }^{\mathrm{V} 600 \mathrm{E}}$ mutation. N. Engl. J. Med. 2011, 364, 2507-2516. [CrossRef] [PubMed]

162. Dummer, R.; Goldinger, S.M.; Turtschi, C.P.; Eggmann, N.B.; Michielin, O.; Mitchell, L.; Veronese, L.; Hilfiker, P.R.; Felderer, L.; Rinderknecht, J.D. Vemurafenib in patients with BRAF (V600) mutation-positive melanoma with symptomatic brain metastases: Final results of an open-label pilot study. Eur. J. Cancer 2014, 50, 611-621. [CrossRef] [PubMed] 
163. Harding, J.J.; Catalanotti, F.; Munhoz, R.R.; Cheng, D.T.; Yaqubie, A.; Kelly, N.; McDermott, G.C.; Kersellius, R.; Merghoub, T.; Lacouture, M.E.; et al. A retrospective evaluation of vemurafenib as treatment for BRAF-mutant melanoma brain metastases. Oncologist 2015, 20, 789-797. [CrossRef] [PubMed]

164. Sakji-Dupre, L.; Le Rhun, E.; Templier, C.; Desmedt, E.; Blanchet, B.; Mortier, L. Cerebrospinal fluid concentrations of vemurafenib in patients treated for brain metastatic BRAF-V600 mutated melanoma. Melanoma Res. 2015, 25, 302-305. [CrossRef] [PubMed]

165. Falchook, G.S.; Long, G.V.; Kurzrock, R.; Kim, K.B.; Arkenau, T.H.; Brown, M.P.; Hamid, O.; Infante, J.R.; Millward, M.; Pavlick, A.C.; et al. Dabrafenib in patients with melanoma, untreated brain metastases, and other solid tumours: A phase 1 dose-escalation trial. Lancet 2012, 379, 1893-1901. [CrossRef]

166. Azer, M.W.; Menzies, A.M.; Haydu, L.E.; Kefford, R.F.; Long, G.V. Patterns of response and progression in patients with BRAF-mutant melanoma metastatic to the brain who were treated with dabrafenib. Cancer 2014, 120, 530-536. [CrossRef] [PubMed]

167. Mittapalli, R.K.; Vaidhyanathan, S.; Dudek, A.Z.; Elmquist, W.F. Mechanisms limiting distribution of the threonine-protein kinase $\mathrm{BRAF}^{\mathrm{V} 600 \mathrm{E}}$ inhibitor dabrafenib to the brain: Implications for the treatment of melanoma brain metastases. J. Pharmacol. Exp. Ther. 2013, 344, 655-664. [CrossRef] [PubMed]

168. Kaufman, H.L.; Wong, M.K.; Daniels, G.A.; McDermott, D.F.; Aung, S.; Lowder, J.N.; Morse, M.A. The use of registries to improve cancer treatment: A national database for patients treated with interleukin-2 (IL-2). J. Personal. Med. 2014, 4, 52-64. [CrossRef] [PubMed]

169. Powell, S.; Dudek, A.Z. Single-institution outcome of high-dose interleukin-2 (HD IL-2) therapy for metastatic melanoma and analysis of favorable response in brain metastases. Anticancer Res. 2009, 29, 4189-4193. [PubMed]

170. Chu, M.B.; Fesler, M.J.; Armbrecht, E.S.; Fosko, S.W.; Hsueh, E.; Richart, J.M. High-dose interleukin-2 (HD IL-2) therapy should be considered for treatment of patients with melanoma brain Metastases. Chemother. Res. Pract. 2013, 2013, 726925. [CrossRef] [PubMed]

171. Vonderheide, R.H.; June, C.H. Engineering T cells for cancer: Our synthetic future. Immunol. Rev. 2014, 257, 7-13. [CrossRef] [PubMed]

172. Hong, J.J.; Rosenberg, S.A.; Dudley, M.E.; Yang, J.C.; White, D.E.; Butman, J.A.; Sherry, R.M. Successful Treatment of melanoma brain metastases with adoptive cell therapy. Clin. Cancer Res. 2010, 16, 4892-4898. [CrossRef] [PubMed]

173. Pardoll, D.M. The blockade of immune checkpoints in cancer immunotherapy. Nat. Rev. Cancer 2012, 12, 252-264. [CrossRef] [PubMed]

174. Azvolinsky, A. One size does not fit all: Personalized immune therapies poised to take center stage. J. Natl. Cancer Inst. 2013, 105, 583-584. [CrossRef] [PubMed]

175. Ott, P.A.; Hodi, F.S.; Robert, C. CTLA-4 and PD-1/PD-L1 Blockade: New Immunotherapeutic Modalities with Durable Clinical Benefit in Melanoma Patients. Clin. Cancer Res. 2013, 19, 5300-5309. [CrossRef] [PubMed]

176. Webster, R.M. The immune checkpoint inhibitors: Where are we now? Nat. Rev. Drug Discov. 2014, 13, 883-884. [CrossRef] [PubMed]

177. Margolin, K.; Ernstoff, M.S.; Hamid, O.; Lawrence, D.; McDermott, D.; Puzanov, I.; Wolchok, J.D.; Clark, J.I.; Sznol, M.; Logan, T.F.; et al. Ipilimumab in patients with melanoma and brain metastases: An open-label, phase 2 trial. Lancet Oncol. 2012, 13, 459-465. [CrossRef]

178. Di Giacomo, A.M.; Margolin, K. Immune checkpoint blockade in patients with melanoma metastatic to the brain. Semin. Oncol. 2015, 42, 459-465. [CrossRef] [PubMed]

179. Knisely, J.P.; Yu, J.B.; Flanigan, J.C.; Sznol, M.; Kluger, H.M.; Chiang, V.L. Radiosurgery for melanoma brain metastases in the ipilimumab era and the possibility of longer survival. J. Neurosurg. 2012, 117, 227-233. [CrossRef] [PubMed]

180. Kiess, A.P.; Wolchok, J.D.; Barker, C.A.; Postow, M.A.; Tabar, V.; Huse, J.T.; Chan, T.A.; Yamada, Y.; Beal, K. Stereotactic radiosurgery for melanoma brain metastases in patients receiving ipilimumab: Safety profile and efficacy of combined treatment. Int. J. Radiat. Oncol. Biol. Phys. 2015, 92, 368-375. [CrossRef] [PubMed]

181. Mathew, M.; Tam, M.; Ott, P.A.; Pavlick, A.C.; Rush, S.C.; Donahue, B.R.; Golfinos, J.G.; Parker, E.C.; Huang, P.P.; Narayana, A. Ipilimumab in melanoma with limited brain metastases treated with stereotactic radiosurgery. Melanoma Res. 2013, 23, 191-195. [CrossRef] 
182. Patel, K.R.; Shoukat, S.; Oliver, D.E.; Chowdhary, M.; Rizzo, M.; Lawson, D.H.; Khosa, F.; Liu, Y.; Khan, M.K. Ipilimumab and Stereotactic Radiosurgery Versus Stereotactic Radiosurgery Alone for Newly Diagnosed Melanoma Brain Metastases. Am. J. Clin. Oncol. 2015. [CrossRef]

183. Qian, J.M.; Yu, J.B.; Kluger, H.M.; Chiang, V.L. Timing and type of immune checkpoint therapy affect the early radiographic response of melanoma brain metastases to stereotactic radiosurgery. Cancer 2016. [CrossRef]

184. Schartz, N.E.C.; Farges, C.; Madelaine, I.; Bruzzoni, H.; Calvo, F.; Hoos, A.; Lebbe, C. Complete regression of a previously untreated melanoma brain metastasis with ipilimumab. Melanoma Res. 2010, 20, 247-250. [CrossRef] [PubMed]

185. Silk, A.W.; Bassetti, M.F.; West, B.T.; Tsien, C.I.; Lao, C.D. Ipilimumab and radiation therapy for melanoma brain metastases. Cancer Med. 2013, 2, 899-906. [CrossRef] [PubMed]

186. Tazi, K.; Hathaway, A.; Chiuzan, C.; Shirai, K. Survival of melanoma patients with brain metastases treated with ipilimumab and stereotactic radiosurgery. Cancer Med. 2015, 4, 1-6. [CrossRef]

187. Weber, J.S.; Amin, A.; Minor, D.; Siegel, J.; Berman, D.; O’Day, S.J. Safety and clinical activity of ipilimumab in melanoma patients with brain metastases: Retrospective analysis of data from a phase 2 trial. Melanoma Res. 2011, 21, 530-534. [CrossRef] [PubMed]

188. Goldberg, S.B.; Gettinger, S.N.; Mahajan, A.; Chiang, A.C.; Herbst, R.S.; Sznol, M.; Tsiouris, A.J.; Cohen, J.; Vortmeyer, A.; Jilaveanu, L.; et al. Pembrolizumab for patients with melanoma or non-small-cell lung cancer and untreated brain metastases: Early analysis of a non-randomised, open-label, phase 2 trial. Lancet Oncol. 2016, 17, 976-983. [CrossRef]

189. Kluger, H.M.; Zito, C.R.; Barr, M.L.; Baine, M.K.; Chiang, V.L.; Sznol, M.; Rimm, D.L.; Chen, L.; Jilaveanu, L.B. Characterization of PD-L1 expression and associated T-cell infiltrates in metastatic melanoma samples from variable anatomic sites. Clin. Cancer Res. 2015, 21, 3052-3060. [CrossRef] [PubMed]

190. Ahmed, K.A.; Stallworth, D.G.; Kim, Y.; Johnstone, P.A.; Harrison, L.B.; Caudell, J.J.; Yu, H.H.; Etame, A.B.; Weber, J.S.; Gibney, G.T. Clinical outcomes of melanoma brain metastases treated with stereotactic radiation and anti-PD-1 therapy. Ann. Oncol. 2016, 27, 434-441. [CrossRef] [PubMed]

191. Lawrence, M.S.; Stojanov, P.; Polak, P.; Kryukov, G.V.; Cibulskis, K.; Sivachenko, A.; Carter, S.L.; Stewart, C.; Mermel, C.H.; Roberts, S.A.; et al. Mutational heterogeneity in cancer and the search for new cancer-associated genes. Nature 2013, 499, 214-218. [CrossRef] [PubMed]

(C) 2016 by the authors; licensee MDPI, Basel, Switzerland. This article is an open access article distributed under the terms and conditions of the Creative Commons Attribution (CC-BY) license (http://creativecommons.org/licenses/by/4.0/). 